\title{
Multiculturalism/multinationalism and multi- and intercultural education - an essay on a meandering tradition and the uneasy modern times (the case of Poland)
}

\begin{abstract}
The study is a presentation - in an essayistic and exemplary approach - of the meandering history of multiculturalism and multinationalism in Poland. This history until 1918 is described in two dimensions - firstly, a rather peculiar and in fact harmful multiculturalism of rulers' world (mostly foreign election kings and later aggressors) and, secondly, the developing, increasingly richer and introducing important values, multiculturalism of people. This is followed by an outline of the changes after 1918 (mostly the crisis of the multinational state), as well as after 1945 and 1989 - the birth of a national state in two different political systems. The recent years are the times of drifting apart from a pro-European (open to multiculturalism) state in favour of a state and a substantial part of the society which is increasingly less democratic and contests European and global problems. This constitutes the background for the discussed issues of multicultural education. What has been also considered is the (developed in Poland) concept and practice of intercultural education. Intercultural education seems to enhance in the best way the familiarization with and understanding of Others and, in consequence, the shaping of positive relations among people.
\end{abstract}

Keywords: multinational state, national state, multiculturalism, multicultural education, socio-political paradoxes, intercultural education, politics and/or education

** *

Multiculturalism is a common phenomenon. It is generally associated with national and ethnic diversification and - in compliance with its meaning with a diversity and multitude of man-made cultures. These diversities constitute a wealth and a chance for the development of societies and individuals. Yet, human history seems to confirm that multiculturalism is a reason 
of - and sometimes rather a pretext for - conflicts, wars, tragedies. In spite of its various limitations, aberrations and weaknesses, what brings hope for eliciting the good sides of multiculturalism and preventing bad phenomena is education. Its special field is multicultural and intercultural education. The differentiation between the two in the discipline of pedagogy will be discussed further.

In a book addressed mostly to foreign readers, it seems recommended at least to outline the complicated history of multiculturalism in the Polish territories. What should be discussed against this background are the current ways of understanding and implementing multicultural and (which might even be more important) intercultural education that have come into being in Poland. In an abbreviated approach, some selected - but as I presume meaningful and characteristic peculiarities of the past and current history of multiculturalism.

\section{The meandering history of multiculturalism in the past centuries ${ }^{1}$}

\section{The beginning of multiculturalism in the times of the Piast dynasty}

Referring to the knowledge of the past, let the coursebook (also encyclopedic) knowledge be addressed at first. The first more broadly known ruler was Mieszko I (about 960-992). His predecessors, or rather local tribal rulers, were Siemowit (Ziemowit), Lestko (Leszko) and Siemomysł (Ziemomysł). Mieszko I accepted Christianity in 966 and got married to Dobrawa (the daughter of Boleslaus I, the Duke of Bohemia), who was given a Polish name Dąbrówka. Those events - contacts with the Bohemian royal court and the Czech wife, as well as accepting a religion that was quite popular in a big part of Europe - were the first experiences of multiculturalism in the early Polish state. The origins of the state organism are usually associated with Greater Poland, especially with Gniezno and Poznan as the towns in which the lay and church (bishopric) authorities were seated.

According to some other historical views, the organizational beginning of the state can be attributed to the newcomers from Moravia. State structures - to a certain extent following the Moravian experiences - were formed in

1 The historical outline is based on coursebooks and studies on the history of Poland, as well as on encyclopaedic sources - all provided in the bibliography. 
Lesser Poland, near the border with Bohemia. Among other names, Wiślica and Krakow are mentioned as the seats of the ruling authorities.

Not going into historical debates - as this is the domain of specialists my intention is to emphasize the distinct traces of multicultural relations of the early rulers. Those were important relationships (e.g. accepting Christianity or joining the European politics and culture) which determined the later history of Poland and Poles.

The process of creating a strong state also involved some less friendly (and tragically marked in the history of humanity) encounters with people and their cultures. The state grew in size and wealth as a result of wars. Mieszko I's son - Boleslaus I the Brave - took Bautzen (Lusatian territories), Olomouc (Moravia) and Nitra (Western Slovakia). That was a period of the consolidation of the state. In 1025 Boleslaus the Brave's coronation took place, which was the culmination of the efforts to recognize the ruler's authority and the status of an independent state.

The following years turned out to be less favourable. The inner conflicts and the ones with the neighbouring countries weakened the state ruled by the Piast dynasty. In the $12^{\text {th }}$ and $13^{\text {th }}$ century, the state was divided into duchies/districts. The partition was initiated by Boleslaus the Wrymouth, who distributed the districts among his sons. The dominating role was fulfilled by the duke residing in Krakow. In practice, conflicts were inevitable and the state lost its significance. The ruling was hindered by the frequent changes of the dukes in the Krakow district. In 1138-1306, 21 dukes ruled there, including a few Czechs at the turn of the $13^{\text {th }}$ and $14^{\text {th }}$ century. Only two of them Premislaus II and Wenceslaus II (one of the aforementioned Czechs) - were crowned and became kings of Poland. A difficult and successful struggle for reuniting the Polish lands was undertaken by Ladislaus the Short (crowned in 1320). However, the territories of the state were shrinking.

This unpromising image of the state should not obscure the changes in more and more multicultural societies. The competition among district dukes, contacts with other countries, trade, attracting artists, construction specialists and advisors from different countries created a favourable climate for familiarization with the people who came to the Polish territories and with their cultures, as well as for benefitting from those cultures.

Some signs of changes distinctly appeared during the rule of Casimir III the Great (1333-1370). It is said that he found the wooden Poland and left it stoned. This was possible owing to, among others, craft masters, construction specialists and artists from other countries. Apart from the newcomers from 
the neighbouring monarchies, e.g. Armenian and Jewish communities found their home in various towns. The lasting material proofs of this are e.g. the $14^{\text {th }}$ century Armenian cathedral in Lviv (during Casimir the Great's rule and many years in another period, a town within the borders of Poland, to a large extent created and inhabited by Poles) and Kazimierz - a Jewish town in the $14^{\text {th }}$ century bordering Krakow (since the $18^{\text {th }}$ century, a district of Krakow, with many well-preserved objects of the Jewish culture, functioning as a lively cultural centre). Over the years, such examples were more and more frequent.

The number of foreigners in Poland - Czechs, Germans, Italians, Russians, Armenians, Jews and many others - also increased. They benefited from the favour of rulers, various patrons, estate (town, land, etc.) owners. They enjoyed the rights which they had been granted and tolerance. This is a good and beautiful tradition.

What confirms the shaping of a multicultural environment of scientists and people who wanted knowledge is the establishing in 1364 in Krakow of one of the oldest universities in Europe. Without a doubt, its foundation was enhanced by a large concentration of scientists and students from various regions and countries in this town.

\section{The Angevins related to the Piasts and Jagiellonians on the throne and the multicultural population}

In 1370, Casimir the Great dies, which marks the end of the Piasts' rule. The further state rule gains new international - and hence multicultural - dimensions. At first, Poland had a Hungarian king - Louis I the Great, sometimes called, Louis of Hungary (in Poland known as Louis the Hungarian), who became the king of Hungary in 1342 and of Poland in 1370. He came from the House of Anjou and was a son of Charles I (also called Charles Robert) and, what is worth emphasizing, of Elizabeth of Poland (a daughter of Ladislaus the Short). The motives for this choice are not going to be discussed here, but it contributed to the closeness of both states and nations. This was a stage in history which must have had due significance (alongside some later events) in forming the belief in the brotherhood of Poles and Hungarians. In both countries, there is a well-known saying: "Poles and Hungarians are like two brothers - both in fighting and in drinking". Louis the Great's reign was very successful in Hungary and he also made efforts to rule Poles very reasonably.

Louis was succeeded by his daughter Jadwiga. In order to strengthen Poland (especially in the face of outer threats), some allies were sought. 
Thus, Jadwiga's marriage to the ruler of Lithuania (Ladislaus Jagiello, Pol. Władysław Jagiełło) was arranged. In 1385, in the Act of Kreva, the Polish throne was taken over by the Great Duke of Lithuania - Ladislaus Jagiello. A personal union united the two countries - Poland and Lithuania (the Great Duchy of Lithuania). As it turned out, this was an efficient defence mostly against the Teutonic Order, which was brought to Poland in 1226 with good intentions to gain an ally by Konrad of Masovia. Against his expectations, Teutonic Knights turned out to be aggressive and possessive enemies.

The fate of the Polish-Lithuanian Union was not easy in many aspects. A major hindrance resulted from different priorities of general politics. The threats for Poland as well as good and bad relations were associated with the western and Northern neighbours. Lithuania - with a much larger territory than Poland (comprising the current areas of Lithuania, Belarus and Ukraine) was engaged in different relations mostly with its eastern and southern neighbours. Ruling the state from two remote centres was not easy. Quite often, the aims of the Polish and Lithuanian rulers were diverse and there was not enough good will and trust. In the long history of the Polish-Lithuanian Union, lasting from the Act of Kreva in 1385 to the partitions of Poland in the second half of the $18^{\text {th }}$ century, the conditions of collaboration, rights and duties were often negotiated. Some agreements, called unions, were made - in the aforementioned Kreva, and later in Vilnius and Radom, Horodło, Grodno, Vilnius, Mielnik and Lublin. The Polish-Lithuanian relations after 1572 were negatively influenced by the end of the Jagiellonian dynasty.

The Jagiellonian rule lasted from Ladislaus Jagiello to Sigismund II Augustus. As emphasized earlier, it was a relatively complicated period in ruling the state but, on the other hand, it largely broadened the contacts with people of other cultures, religions and customs. The Polish-Lithuanian Commonwealth, as later the union was sometimes called, was a strongly diversified organism in regard to nationality, ethnicity, religion, language, and culture in general. This cultural diversity resulted from the diversification of the population living in the vast area between the Baltic and the Black Sea, as well as the area from the borders of German states and Bohemia to Moscow and Ryazan duchies and Crimean Khanate (in the $15^{\text {th }}$ century), or later in the already reduced territories from the Kingdom of Prussia and Austria to the Russian Empire and Turkey (in the $18^{\text {th }}$ century). Over the time, the diversification increased due to the growing numbers of newcomers from other countries. 


\section{Election (mostly foreign) kings and multinational/multicultural population}

In 1573, an important change was introduced in the political life. During the convocation sejm, it was decided that kings would be chosen by election. That decision brought about a kind of specific multiculturalism in royal elections. The divided electors, in many cases subjected to the influence of foreign royal courts and attracted by material benefits and promises of profitable positions, were unable and/or did not want to choose a good candidate among their own group. Foreign candidates were favoured in hope for various political profits and influences.

The first elected king was Henry III of France (Pol. Henryk Walezy). He was not much interested in the Polish matters, contrary to the events in France. He left Poland already in 1574 (it is said that he did it secretly) and took over the throne of France after his brother. The next elected one was the Prince of Transylvania Stephen Bathory (Pol. Stefan Batory). He was considered to be a good ruler, although the war with Russia for Livonia was going on during his reign. After the Frenchman and Duke of Transylvania, there were three kings from the House of Vasa - Sigismund III Vasa, Ladislaus IV Vasa and John II Casimir Vasa. That was a period of the conflicts and wars with Swedes. The Swedish invasion of Poland during John Casimir's reign caused huge devastation. The king (from the House of Vasa - a Swedish dynasty) conducted a fratricidal war on the Polish side.

After the Vasa kings, Michael I (Michał Korybut Wiśniowiecki) was elected and then John III Sobieski. The latter turned out to be an excellent ruler and leader - he won the battle of Chocim and the defence of Vienna (in 1683). His victorious participation in the battle of Vienna brought about his fame as a defender of Europe against Turks.

After Sobieski, the meandering political history gave Poland kings from the House of Wettin - Saxon elects. Their rule involved electing Stanislaus I Leszczyński twice - the first time, he was supported by the Northern neighbours and, at his second election, by Lois XV, the king of France and Leszczyński's son-in-law (the husband of Leszczyński's daughter Marie). This period was marked with chaos, anarchy, weakness of the state. The situation was worsened by long-lasting wars and the rebellions in Ukraine. Poland was losing territories, the conflicts between the mighty were weakening the state, international significance of a former European power was shrinking. 
In regard to the royal elections and kings' reigns, multiculturalism did not result in success. Only few of the foreign rulers wanted and were able to care for the state and its people. Many of them were too much involved in preserving their power, in dealing with the mighty, and in the issues of their home countries.

It should be added that in Europe there have always been examples of taking over thrones by foreign people or dynasties. Yet, it is hard to find such a changeability and number of ruling foreigners as in Poland. The throne was taken over by Czechs, Lithuanians, the King of Hungary, a Frenchman, the Duke of Transylvania, Swedes, and the dynasty of German rulers. Against some hopes of the mighty, various alliances did not strengthen Poland. What grew were the influences of Polish clans (which supported foreign rulers) and of the neighbouring countries (engaged in promoting foreign candidates and then the elected kings).

The history of royal rule outlined above might not provide an encouraging image of multiculturalism as regards electing the people to whom the throne was entrusted. At the same time, this history co-occurs with the phenomenon of growing multiculturalism among the population. There were more and more foreigners - people of different professions, religions, languages. Particularly in big towns, the communities of various nationalities and cultures grew in size - Germans, Ruthenians, Armenians, Jews. Churches, synagogues, Orthodox temples came into being in many places. In Lviv, cathedrals of several denominations were built - the Armenian, Roman-Catholic and Uniate ones. In Zamość, a town founded in the $16^{\text {th }}$ century, there have been streets the names of which commemorate different nationalities of its residents. Substantial religious tolerance in Poland enhanced the settlement of foreigners representing other religions. This can be exemplified by the case of the religious immigrants from Bohemia, called the Czech Moravian Brethren, who settled in Poland, mostly in Leszno. Among others, John Amos Comenius stayed in this town in 1628-1655, working as a teacher and the head of the school (gymnasium) there. Many foreign artists (e.g. Germans and Italians) created their works in Poland. For centuries, Jews have substantially contributed to various fields of life.

Thus, multiculturalism had a large and in many aspects positive influence on social life - on trade, art, science, crafts, building and other areas of social activity. In contrast to the experiences associated with foreigners on the Polish throne, the multiculturalism of many social environments, manifested in various spheres of people's life, brought about cognitive benefits, shaped 
attitudes, enhanced development of people and their spiritual and material culture. Therefore, this constitutes a platform and a dimension in which special values related to multiculturalism in Poland can be seen.

This special clash between the multiculturalism of political elites and multiculturalism in other spheres of life seems to be a peculiarity which is worth considering in the attempts to understand the later history of Poland and Poles - including the history of multiculturalism and social behaviour in the face of it. Thus, this motif is bound to return in this study.

\section{The last election king - a Pole who tried to save the fate of Poland}

The last election king - Stanislaus II Augustus (Pol. Stanisław August Poniatowski), who reigned in 1764-1795, tried to save the fate of Poland. He made efforts to accelerate the development of economy, which lagged behind the economies of West-European countries. He undertook similar efforts in the field of education and culture. The reforms had positive effects. The impact of the Enlightenment ideas turned out to be significant. The foundations for modern (in those times) industry were laid. In 1773, the Commission of National Education was founded - it was considered the first department of education in the world. The Commission prepared and partially implemented educational reforms.

Poniatowski counted on the favourable attitude of Russia. Unfortunately, the effects of previous negligence and the weakness of the state resulted in the I Partition of Poland. In 1772, Russia, Prussia and Austria took over large territories of the state. Then, the struggle went on to strengthen the independence from the neighbours, mostly Russia. In May 1791, a constitution was adopted which aimed at making the state contemporary and at broadening civil rights (by granting them to townspeople). All rescue attempts were too late. An additional hindrance came with the rebellion of magnates, who supported by Catherine II and the Russian army - abolished the reforms. With the participation of Russia and Prussia, the II Partition of Poland took place and in 1795 - the III Partition, which put an end to the Polish state.

\section{Difficult multiculturalism in the time of partitions and the struggle for Polishness and independence}

What came later was a time of different multiculturalism. The Napoleon wars brought back the hope for reconstruction of the state. Many Poles engaged 
in these wars and fought on the side of the French emperor. The belief in the rebirth of Poland and their soldier wows led them with Napoleon all over Europe. However, this also involved morally ambiguous events, such as e.g. participation in wars which deprived other nations and states of independence. In 1807, the Duchy of Warsaw came into being - a transitional form of statehood made up of the territories taken by Prussia and Austria. It was associated with the Kingdom of Saxony and was actually subordinated to Napoleon I. Its existence ceased after Napoleon's fall in 1815. By the resolution of the Congress of Vienna, the Kingdom of Poland (often called the Congress Kingdom) was established. It was subordinated to Russia.

What took place in the territories taken by Russia and Prussia was denationalization - russification and germanization were increasing. Various forms of struggle were undertaken in protest. Some uprisings broke out, which triggered repression - mostly in the area under the Russian supervision. The exile to Siberia was a frequent punishment. Many Poles emigrated, mainly to France. In the territories under partitions, the process took place of imposing the dominating culture. Citizen liberties were reduced. After the November Uprising in 1831, the already reduced autonomy was limited even more and after the January Uprising in 1863-1864, all liberties were abolished. Over the time - in 1874 - the Kingdom of Poland was resolved and the rule was granted to the governor appointed by the tsar. The former kingdom was called the Vistula Land.

More favourable conditions for life were in the Austrian-Hungarian Empire. In this multinational and multicultural state, people could have more freedom and tolerance, as well as possibilities of the preservation of their language and culture. People of various nationalities from other parts of the monarchy came in growing numbers to the territories of the Austrian partition. Yet, the assimilation process took place there.

In the long period without Poland as an independent country on the maps of Europe, which lasted for 123 years, strong tendencies to identify with Polishness appeared. Against the pressure of occupiers, the patriotic current in literature and art intensified. Great significance was attributed to the creativity of emigrants whose works reached Homeland. The Polish identity drawing from many cultures started to crystalize in a society that had been multicultural for centuries. In these condition, Frederic Chopin drew inspiration from both French and Polish culture and created music widely associated with Poland. With his multicultural inspirations, one of the greatest prophets - a poet Adam Mickiewicz - wrote his works both in the homeland and 
in emigration (Russia, France). Recognized as a remarkable figure of Polish culture, deeply engaged in Polish issues, he is considered by Lithuanians and Belarussians as a representative of their cultures as well. Culture and industry were created by representatives of various nationalities - Poles, Germans, Jews, Russians and many other. There are numerous examples.

However, it should be stated that life in a multicultural society was not free of conflicts. Especially in the $17^{\text {th }}$ century, the rebellions of Ukrainians intensified. In the times of partitions, a surge of mass murders aimed at Jews rolled over the territories supervised by the tsar. Emigration grew in force Poland was left by the poor, work-seeking, as well as talented people heading for success or by the persecuted ones. This pertained to Poles and Jews, but - to a certain extent - also to other nationalities. Over the time, the population inhabiting Belarus and Ukraine developed a stronger feeling of cultural and national separateness, a feeling of their own identity. The signs of differentiation were distinct, on the one hand, there were Polish noblemen, land owners and townspeople, and on the other one - Ukrainian and Belarussian peasantry. Yet, in general, Polish territories were for centuries inhabited by communities of various nationalities and ethnicity, who lived in peace. With large evidence that proves this, it seems that in this aspect Poland was one of the few good examples of a multicultural but at the same time tolerant state - open to Others and other cultures.

All this - the peculiar political history, changing social relations, history of culture - have influenced the meandering history of multiculturalism in Poland - from the state's beginning, through its various ups and downs, to the regaining of independence after 123 years of captivity.

\section{Multiculturalism in Poland from regaining independence in 1918 until today}

\section{The reconstruction of a multinational and multicultural state}

The hope for regaining independence and rebirth of the state could be fulfilled after the stormy events which took place in Europe in the 1910s. The world war, revolutions in Russia and Germany, the fall of tsar rule, the war lost by Germany and the end of the Austrian-Hungarian monarchy (Poland's occupiers) turned out to be favourable for the restoration of the state. The resolution was to be taken on the peace conference in Paris after the war. The winning Entente countries were interested in limiting the influences of 
Germany and Russia and, therefore, they were favourably approached the intention of restoring Poland and indicating its new borders.

This favour was enhanced by over a hundred-years-long struggle of Poles for independence, their participation in numerous uprisings, wars and liberation-aimed activities, undertaken with the intention to bring Poland back to life. What was also important were the relations between the emigration and the societies of the countries which accepted immigrants (mostly France and Great Britain). In the fresh memories of Frenchmen - significant participants of the Paris conference, there was the participation of Polish volunteers from the Bayonne Legion alongside the French Foreign Legion. In 1914-1915, the Bayonne Legion fought in several battles on French territories.

A lot of significance should be attributed to diplomatic and other contacts of well-known Poles with politicians from the countries that won the war. Among the most important contacts are those of an outstanding pianist Ignacy Paderewski (Prime Minister of Poland in 1919-1920, a representative of Poland in the League of Nations), who presented Polish issues e.g. to Thomas Woodrow Wilson, the President of the United States. As it is known, T.W. Wilson largely contributed to the course and accepting the resolutions of the peace conference. He was the author of the Fourteen Points, which determined the conditions of peace. One of them concerned the creation of (independent) Poland.

What should be also mentioned are the activities of various armed formations, at first associated with the occupiers' armies but later (during the war) undertaking liberation actions. The greatest significance was attributed to the Polish Legions and their founder - Józef Piłsudski.

A coincidental occurrence of many events and the activities of Poles resulted in Poland's regaining independence in 1918.

As regards the basic motif of multiculturalism, it ought to be emphasized that the newly created state organism consisted of people from the territories which for a long time had been under the legal system, cultural and social influences, and the impact of different countries and societies. In many aspects, the nationality composition and the cultures were different in each of the occupying empires. This determined the experience of people living in each of them and, to a certain extent, shaped the images and expectations concerning the reborn Polish state. It seems worth adding that some typical (dominating in particular communities) behaviour patterns can be still noticed today among the descendants of the inhabitants living in the areas belonging to different occupiers. Even after a hundred years after regaining independence, 
some differences can be seen in the living standards, urbanization, industrialization, railway and road networks in the territories of former partitions. The beginning of the reborn state revealed various issues of broadly understood multiculturalism. In this context, two competitive concepts of state and society were formulated - one focused on the vision of national state, the other - the vision of multinational and multicultural state. These concepts and their presence in modified forms will be discussed in the further part.

The rebirth of the Polish state turned out to be difficult, among other factors, due to the conflicts with the neighbours about the borders. The border with Germany was to be determined on the Paris conference. The discussion seemed to result in the view that the majority of industrialized areas (including coal mines) should be given to Germany. Yet, in the Treaty of Versailles, signed in 1919 on the Paris conference, there was a resolution that the state belonging of Silesia should be decided by a plebiscite.

During the conference, it was considered that those were fundamental resolutions. It is said that President Wilson sent a note to his wife saying: "We reached a peace. Everybody is dissatisfied, thus it might be just. Now, everything in God's hands". The President of the USA, who was very favourable to Polish issues, might not predict or might underestimate the effects of leaving some borderland conflicts to be solved by the population living in the conflict areas. As a supporter of people's self-determination, he applied an over-optimistic attitude. Peace did not come to the Polish borderlands and the dissatisfaction of the countries that wanted those territories appeared in a variety of conflicts. Both Poles and Germans were not going to leave the matters in God's hands, as Wilson stated. They undertook actions that were aimed at taking over Silesia and its resources and industry.

Still before the Treaty of Versailles, the I Silesian Uprising broke out. This happened after strikes in mines and steelworks and after killing a couple of people who - in the crowd of miners and their families - were waiting for wages in front of mines in Mysłowice. The struggle was undertaken by the forces of the secret Polish Military Organization of Upper Silesia. It lasted from the $17^{\text {th }}$ to $24^{\text {th }}$ August 1919 and - with the prevailing forces of the German army ended with a defeat. The insurgents did not have enough weapons. What also failed were the expectations that the soldiers of the so called Haller's army, who were coming back from France, would join the struggle (Kaczmarek, 2019).

The conflicts in borderlands continued and in August 1920 the II Silesian Uprising broke out. It resulted in Germans' consent for establishing the Polish-German Plebiscite Police (ibid.). 
The plebiscite (designed in the Treaty of Versaille) took place on the $20^{\text {th }}$ March 1921. 97.5\% of people with voting rights participated in it. 59.4\% chose the belonging to Germany, $40.3 \%$ - to Poland. The result was partially determined by the so called emigrants - people coming from Upper Silesia but without permanent residence there (they constituted $19.3 \%$ of all voters). Germans organized the participation of 182 thousand of such people. 10 thousand the so called emigrants voted for joining Poland. Germans gained majority in the towns of The Upper Silesian Industrial Region, Poles - in, mostly agricultural, counties (ibid.).

Such a result of the plebiscite triggered the III Silesian Uprising. In contrast to the previous ones, it is considered as an undeclared Polish-German war into which both countries engaged - Poland and the Weimar Republic.

The effects of the III Uprising turned out to be rather favourable - contrary to what the plebiscite outcomes would suggest: "The Ambassadors Conference of the League of Nations, after long, almost three-months-long negotiations, elaborated a compromise solution and proclaimed it on the $20^{\text {th }}$ October 1921. Poland got one third of the territory in which the plebiscite took place, but that was the most urbanized area (inhabited by almost half of the plebiscite voters) and a highly industrialized one (out of 67 coal mines, Poland got 53; it got all iron ore mines, two thirds of zinc and lead ore mines, as well as a large share of metallurgical industry" (ibid., p. 19). Some territories inhabited mostly by people who identified with the reborn Polish state remained outside Poland (Pszczyna and Rybnik counties and a part of Lubliniec county).

Armed conflicts broke out also in the Eastern borderlands. Despite the consent of the Soviet Russia to establish the Polish state, since 1919 some struggle went on which was a harbinger of the war for Lithuanian, Belarussian and Ukrainian territories. A large scale war took place in these territories in 1920. The Polish army conducted an attack, as a result of which Kiev was taken over on the $7^{\text {th }}$ of May. The Polish authorities, especially Marshall Józef Piłsudski - the Chief of State, intended to create the conditions for establishing the independent Ukrainian state. It would constitute a precaution - a specific buffer zone - against the dangers coming from Russia. Ukrainians took part in the war (military formations of Ukrainian People's Republic which fought against the Bolsheviks). Their commander was Symon (Semen) Petliura, who in April signed the Polish-Ukrainian agreement. The plan to establish the independent Ukrainian state failed. Russians conducted a counterattack and their army almost reached Warsaw. In August 1920, Poles stopped 
the Red Army in the Battle of Warsaw, which was later widely known as the "Miracle on the Vistula". As its result, the Red Army withdrew from the Polish territories. This was also enhanced by the inner affairs in Russia. The Ukrainians from Petliura's troops were imprisoned in Poland and some of them remained there, enlarging in this way the multicultural society. In 1921, a peace treaty was signed by Poland, Soviet Russia and Ukraine. It kept e.g. the territories of East Galicia and Volhynia within the borders of Poland, which earlier had been accepted by Petliura against his will (Olszański, 2020).

Thus, the Peace Treaty of Riga was a confirmation of the multinational state in which a substantial number of population were citizens of other nationality than Polish.

In the case of Ukrainians, slightly paradoxically, this turned out to be beneficial in various aspects. Tadeusz A. Olszański comments this in the following way: "[...] it turned out that Petliuria's concessions towards Poland were a providential decision: the borderline - indicated in the Warsaw agreement and confirmed in the Peace Treaty of Riga - became the western borderline of the Holodomor (also known as the Terror Famine or Great Famine). Four to five million Ukrainians, citizens of the II Republic of Poland, were not affected by this disaster, nor by collectivization, slaughter of elites and the bolshevization of awareness. For 20 years, they were able to develop in a relatively democratic and law-abiding society. This is why this borderline is also visible today on the political and social map of Ukraine (ibid., p. 59).

Moreover, Spiš and Orava (earlier belonging to Upper Hungary as a part of the Austrian-Hungarian monarchy, mostly inhabited by Slovaks) were comprised within the borders of Poland, as well as a part of Cieszyn Silesia - mostly with the Polish population and (smaller) German and Jewish ones. The lost plebiscite in Warmia and Masuria brought about territorial benefits on a relatively small scale.

It was crucial to gain access to the sea. This meant that, among others, Kashubians and some groups of Warmia inhabitants, with their own cultural traditions and language (the case of Kashubians), found themselves within the Pomeranian voivodeship. Obviously, a Lithuanian community lived in the Vilnius voivosdeship and e.g. Masurians in the Białystok voivodeship. In most of the territories of the reborn Poland, there were relatively large Jewish communities - especially in big and small towns.

All this composed a multinational, multiethnical and multicultural state. To a certain degree, mostly in the East, it reconstructed the earlier pre-partitions mosaic of nationalities and cultures. Partially - especially in the South, 
this was a new diversity. All these elements were to make up the state organism and the society of this state.

\section{A multinational state and society or many nationalities in a state? Poland in 1918-1939}

The multinationalism of Poland in those times is illustrated by the results of the national census in 1921, published in 1925 . The overall population was specified as 27184836 . There were only 6 possibilities of national identification: Polish, Ruthenian, Belarussian, German, Jewish, "other or unknown". These results are presented in Table 1.

Table 1. Nationality of people comprised in the national census in $1921^{2}$

\begin{tabular}{|l|c|c|}
\hline \multicolumn{1}{|c|}{ Nationality } & Number & $\%$ \\
\hline Polish & 18820.163 & 69.2 \\
\hline Ruthenian & 3899.223 & 14.3 \\
\hline Belarussian & 1060.041 & 3.9 \\
\hline German & 1058.824 & 3.9 \\
\hline Jewish & 2111.304 & 0.8 \\
\hline Other or unknown & 235.281 & 100.0 \\
\hline Total & 27184.836 & 0.9 \\
\hline
\end{tabular}

Own elaboration based on: "Rocznik Statystyki Rzeczypospolitej Polskiej [Statistical Yearbook of the Republic of Poland]", $3^{\text {rd }}$ Edition - 1924, Warszawa 1925: Główny Urząd Statystyczny.

In various publications and presentations, the information is provided that after 1918 one third of the population of Poland was of other nationality than Polish. The results of the 1921 census contain more precise data. $69.2 \%$ of the respondents considered themselves to be Poles. Yet, the quoted numbers are not fully accurate. For instance, the number of Upper Silesia inhabitants of Polish, German and other nationality - respectively: 683168 (69.7\% of the population of Upper Silesia), 289776 (29.5\%) and 7352 (0.8\%) - was provided approximately by accepting the nationality percentages from the 1910 census ("Rocznik Statystyki Rzeczypospolitej Polskiej”, 1925). Thus, in spite of their apparent exactness, the provided numbers do not reflect the actual number of people of Polish, German and other nationality in 1921.

Moreover, the numbers pertaining to the Belarussian and Ruthenian nationality are also approximated. There are Ukrainians in the group of Ruthe-

2 I am thankful to Krzysztof Zeniuk for reaching the sources, collecting and sharing the data from the national censuses of 1921, 1946 and 2011. 
nians but it is also quite likely that some Ukrainians were counted as Belarussians. Due attention is drawn to this by some Ukrainian authors (Hawryluk, 1999; Łabowicz, 2013). L. Labowicz notices that "As the Orthodox inhabitants of these territories (Podlasie region to the North of the Bug River - T.L.) did not have a crystallized Ukrainian national identity, still in the interwar period, they were considered to be Belarussian" (Łabowicz, 2013).

Many nationalities, such as the Lithuanian, Slovak or Armenian one, are missing in the census results. They were treated as "others".

Particular nationality groups were the largest in the voivodeships (places) of their traditional residence. Ruthenians constituted the largest groups in the south-eastern and eastern territories - the Volhynia, Lviv, Stanyslaviv and Ternopil voivodeships. The largest groups of Belarussians were in the Białystok, Nowogród, Polesie voivodeships and the Vilnius district - in the north-eastern territories. In some voivodeships, the communities of other nationalities than Polish were prevailing as regards the number of residents - e.g. Ruthenians constituted $68.4 \%$ of all inhabitants of the Volhynia, $69.8 \%$ of the Stanyslaviv, and $50 \%$ of the Ternopil voivodeships.

In all the voivodeships - apart from the Poznan and Pomeranian ones (in 13 voivodeships) - and in Warsaw and the Vilnius district, there were large Jewish communities. For example, in Warsaw there were 252301 Jews (26.9\% of all residents), in Warsaw voiv. 163646 (7.8\%), in Łódź voiv. 270437 (12\%), in Kielce voiv. 215280 (8.5\%), in Lublin voiv. 227902 (10.9\%), Białystok voiv. 163044 (12.5\%), Volhynia voiv. 151744 (10.5\%), Polesie voiv. 91251 (10.4\%) ("Rocznik Statystyki Rzeczypospolitej Polskiej", 1925). These numbers seem worth providing, because most of this population died over twenty years later during World War II.

Residents of German nationality mostly inhabited the Poznań and Pomeranian voivodeships and Upper Silesia. Large groups of them were also in the Łódź and Warsaw voivodeships.

As regards the number of residents in particular voivodeships, different nationality groups dominated. As mentioned before, the territories of former partitions were diversified as regards infrastructure, industry, agriculture and many other issues. This did not enhance the integration and construction of a state organism.

Another hindrance was related to different concepts of the state. The one promoted by J. Piłsudski emphasized the idea of a multinational state, in which people of all nationalities and from all ethnic groups have the same civil rights and participate in the state's life. This was outlined in the consti- 
tution of 1921. Among other things, the agricultural reform was to become a factor that would democratize the society. This reform was determined by the act of 1920 - yet, due to abandoning it, in 1925 another act on the agricultural reform was introduced. However, it was never implemented. Moreover, constitutional civil rights were frequently disobeyed - e.g. in the case of people of other nationalities than Polish (inhabiting eastern territories). This was often manifested in educational issues (which will be discussed later). The concept of an integrated multinational and multicultural society turned out to be hard to implement.

The problems with fulfilling the vision of a multinational state grew bigger because of the supporters of the competitive concept of a national state. The movement of national democracy, led by Roman Dmowski, promoted political solutions aimed at founding a national state. Full civil rights were not obeyed in the case of Belarussian and Ruthenian/Ukrainian population. A hostile attitude to people of Jewish nationality was frequent. Some antidemocratic elements appeared in another constitution of April 1935. The national democracy movement (composed of parties and organizations related to National Democracy) was becoming more and more fascisizing.

The above discussed dualism in approaching the matters of the state and society turned out to be insurmountable. Apart from political issues, the situation in other spheres of life was deteriorating. In 1926, a coup took place, as a result of which Józef Piłsudski got dictatorial rule. The state, which regained independence, did not become a multinational and multicultural organism. It also ceased to be fully democratic.

This course of events is explained by the fact that "[...] National Democracy was a very dangerous group for the state - its vision of a national state, struggling against Jews, Ukrainians, whose voting and other rights were to be reduced. In a similar way, the reduction of workers' rights was aimed at, as well as imposing one worldview to the whole state. This was extremely dangerous, it could blow up the whole country - because how to judge placing $1 / 3$ of non-Polish citizens in sharp opposition to the state; and the political and economic projects must have trigger a firm reaction of workers, who were not willing to resign from their justly granted rights" (Friszke, 2020, p. 63).

The situation after the coup in May 1926 is aptly reflected in the following opinion: "[...] after May, many bad things happened. Bribery among some opposition activists in order to get them out of their party or buy newspaper headlines. Enforcing personal changes in courts to make them more 
submissive. Introducing the censorship of press. These were all activities of an authoritarian, not democratic, rule. Piłsudski created a system in which a pluralistic parliament existed but could neither control the government nor abolish it or form a government different than the one Piłsudski wanted. When he realized the threat from the centre-left wing coalition, he ordered to arrest several oppositional deputies, imprison them in the fortress in Brest for a couple of weeks and put them "through the wringer". The elections carried out under pressure, among detentions and resolving all rallies (and partially forged in the eastern borderlands) gave the Sanation over 50\% of mandates. The deputies freed from Brest were judged and sentenced to several years in prison, e.g. Wincenty Witos (the leader of people's movement, Prime Minister in 1920-21, 1923 and 1926 - T.L.). Poland became a multi-party state, the parties could organize conventions and demonstrations, release press, but they could not change the ruling authority" (ibid., p. 63).

This lengthy quote is provided here as this opinion of a well-known historian might partially be associated with the situation of contemporary Poland. This is not a model to follow. This description can help to understand better the sources and image of the current socio-political condition in Poland.

The political climate in the interwar period, conflicts between parties, economic problems, and some signs of unwillingness (even hostility) towards people of non-Polish nationality destroyed the vision of a democratic multinational state. The attempts to polonize Belarussians and Ukrainians became increasingly frequent. Polish officers placed in reserve were resettled into eastern territories. The children deprived of minority education were subjected to assimilation (this will be discussed later). In compliance with the intentions of the authorities, polonization - or in fact specific colonization of eastern regions and their inhabitants was taking place. What returned and grew in intensity was the stereotypical division into "Polish lords" and the local indigenous population of Belarussian and Ukrainian territories. Also the division was consolidated into "Polish towns" and villages mostly inhabited by population of non-Polish nationality.

Another growing phenomenon was stigmatization and signs of hostility towards Jews. This was manifested even in academic environments (cf. e.g. Bukowska-Marczak, 2019) - special places ("bench ghettos" in lecture rooms) were established in universities, the numerus clausus principle was introduced, anti-Jewish rallies were organized.

The relations between the central authorities and the Silesian local government and Silesians turned out to be complex and not good enough. There 
was no interest in the problems of Silesia, there was no trust, Silesia was treated as a source of profits from its well-developed industry. What became a striking example of bad relations was the imprisonment (in 1930) of Wojciech Korfanty - an outstanding Silesian activist, a Polish plebiscite commissary (in 1021), the commander of the III Silesian Uprising, one of the leaders of Christian Democracy and Vice-Prime Minister in 1923.

These selected facts and phenomena illustrate the failure of an attempt to fulfil the vision of a democratic country that links the population of various nationalities. During the two interwar decades, bringing together people of various nationalities and cultures did not take place. It was even worse - with real force and on a scale not known before (in Poland before partitions), the phenomena of intolerance, national chauvinism, hostility and aggression towards Others appeared.

The relations with the neighbouring countries were not good either. The situation of the multinational (and multicultural - e.g. involving various religions) state was getting worse.

It should be highlighted once more that my focus here is mostly on the issues of multinationalism and multiculturalism. Obviously, I can see and appreciate the efforts of the authorities at that time to create modern industry, infrastructure, to build a port on the Baltic. However, all this was not enough to handle the military and industrial power of Germany or the population potential and natural resources (as a consequence - industrial-armament potential) of Soviet Russia. Building the possible power of the Polish state was much more difficult with a mosaic of various nationalities than in the case of a well-functioning integrated state organism. Creating such an organism was not feasible and/or not wanted.

Still, it should be added that the underdevelopment of the reborn Poland - its industrial condition, general economic potential, military force - was so big that even with a lot of effort made by all groups of the population in Poland and with a very wise policy of those who managed that effort, there were hardly any chances for an efficient defence against the approaching war. Whereas the co-occurrence of certain matters in 1918 was very favourable for the rebirth of Poland, the inner and outer situation in 1939 turned out to be extremely unfavourable for its preservation. 


\section{The war years (1939-1945). Another time without independent Poland. Different fate of the nations of the former multinational state}

September 1939 revealed the weakness of the Polish state. The daring announcements that "we will not give a single button" were not confirmed in reality. One part of Poland was taken over by the German army and after a couple of weeks - in compliance with the Molotov-Ribbentrop Pact - the other (eastern) part was taken by Soviet troops. The occupation years began.

The population in eastern territories (with large numbers of people of Belarussian, Ukrainian and Lithuanian nationality) found themselves in a new situation. For many of them, this brought about the hope for a better fate in a state with culturally related people. For other, this was a threat to almost all liberties and life. The tendencies appeared to gain at least some substitutes of statehood. The hopes and dreams dispersed soon, though some acts of the new authorities, e.g. in educational matters, might seem favourable to Belarussians and Ukrainians.

The occupiers treated elites in the same way. Both Germans and - generally speaking - Russians - made staff purges, started the extermination of scientific environments, intellectuals and freelancers. This painfully affected people of Polish nationality.

From 1941, after the German aggression at the Soviet Russia, all the territories of the former Polish state were under the German occupation. The attitudes of people of non-Polish nationality were various - from collaboration with the occupiers, through willing or unwilling passiveness, to different forms of struggle. Even more complex attitudes appeared after $1943-$ some parts of the non-Polish population joined military formations (allied to the occupiers), some engaged in guerrilla movements against Germans, and later some of them - against Russians. On the eastern territories, there were armed battles between Polish guerrillas and the guerrillas from other nationality groups. Unfortunately, civilian population was also harmed. In this combination of conflicts and armed actions, it is hard to find any signs of unity among the citizens of the II Republic of Poland - a republic of many nations.

The time of World War II is a period of heroic struggle with occupiers, of efforts to preserve the language, culture, and national identity. This involves such heroic and tragic events as the uprising in the Warsaw ghetto in 1943 or 
the Warsaw Uprising in 1944. That time took its toll - about 6 million killed people, mass murder of Jews, genocide committed by the occupiers. That was also the time of ordeal that tested human attitudes.

In July 1944, the first institutions of the again reborn state were established on the territories freed from the German occupation. In 1945, Poland was born again within new borders - without the Lithuanian, Belarussian and Ukrainian territories. The attractive but difficult history of the multinational state (in the traditional form) comes to an end. Belarus, Lithuania and Ukraine became republics of the USSR.

\section{Inconvenient (unwanted?) multiculturalism in 1945-1989}

Once again Poland got different borders than before losing independence. Instead of the eastern territories, it gained the areas in the North (with a few hundred kilometres of the access to the Baltic), in the West (as far as the Oder and the Lusatian Neisse), the South-West (Lower Silesia), as well as the territories in Warmia, Masuria, and Upper Silesia.

The change of borders also resulted in the structure of nationalities of Poland's residents. This is illustrated by the results of the national census conducted on the $14^{\text {th }}$ February 1946. In the overall presentation of these results, only four categories were considered: Poles, "people during a rehabilitation or verification procedure", Germans, and "others". Moreover, a group was distinguished of people whose nationality was indefinite (Table 2).

Table 2. Nationality of people comprised in the national census in 1946

\begin{tabular}{|l|r|r|}
\hline \multicolumn{1}{|c|}{ Nationality } & Number & \multicolumn{1}{c|}{$\%$} \\
\hline Polish & 20520.178 & 85.7 \\
\hline People during a rehabilitation or verification procedure & 417.431 & 1.7 \\
\hline German & 2288.300 & 9.6 \\
\hline Other & 399.526 & 1.7 \\
\hline People not taken into account in the division into nationalities & 304.322 & 1.3 \\
\hline Total & 23929.757 & 100.0 \\
\hline
\end{tabular}

Own elaboration based on: Powszechny Sumaryczny Spis Ludności [National Census of Population], 14 II 1946. Warszawa 1947: Główny Urząd Statystyczny.

The census, conducted several months after the end of the war, allowed to capture the general image of nationalities and drew attention to certain phenomena taking place at that time. What was going on was the repatriation of Germans from Poland to Germany and, at the same time, of Poles - 
mostly from the East - to Poland. The action of populating the western territories (called Regained Territories) was taking place. The authors of the report presenting the census results stated that the re-settlement action of the Belarussian, Ukrainian and Lithuanian population was going on as well (cf. Powszechny Sumaryczny Spis Ludności, 14 II 1946, 1947).

The report also comprised the data concerning the leaving of Poland by people of German nationality. According to the official data, in the period from the census (February 1946) to the end of December 1946, 1615555 Germans left Poland.

What seemed to be a sign of the times were the people of indefinite identity (e.g. those who did not provide their nationality) or the people during a rehabilitation or verification procedure aimed at clarifying their war history and behaviour. In total, there were over 700 thousand of such people (3\% of the all people included in the census).

Over the time, the number of people leaving Poland increased. It is estimated that in 1944-1946 almost 500 thousand Ukrainians were resettled in Ukraine. This took place in compliance with the agreement on mutual repatriation between Poland and the USSR. About 200 thousand Ukrainians remained in Poland. In April, the action called "Wisła [The Vistula]", which was aimed at them, started - it consisted in displacing the Ukrainian population from these territories and resettling them in various regions of the area earlier inhabited by Germans. The main argument was depriving the Ukrainian Insurgent Army (which undertook armed guerrilla actions still for several years after the war) of their background. The action was aimed at dispersing Ukrainians in various places and at making assimilation easier (cf. e.g. Łabowicz, 2013).

The already mentioned author - a representative of the Ukrainian minority, who completed university studies in the field of Polish and Ukrainian philology, a teacher of Ukrainian, a press and TV journalist - comments the situation at that time in this way: "Substantial dispersion of the Ukrainian population after 1947, poverty, the feeling of temporality, and the anti-Ukrainian policy of the people's government aimed at justifying the displacement action disseminated a negative image of Ukrainians in the society. All this hindered the rebirth of Ukrainians' socio-cultural life in Poland (ibid., some references to various Ukrainian sources there as well).

Belarussians were also treated with certain reservations. They were reproached for fraternizing with Soviets in 1929-1941 and for their manifestations of accepting the German occupation in 1941-1944. 
Obviously, Germans were treated with even more reservations. The recent tragic experiences enhanced generalizations. Suspicions and accusations concerning all Germans were easily formed. As mentioned earlier, many people of German nationality left Poland in 1946, some others - in later periods.

Generally speaking, with regaining its statehood in 1944/1045, Poland ceased to exist as a multinational state - a country with large numbers of nonPolish citizens. This was compliant with the politics of the ruling authorities, which promoted the slogan of national unity. Paradoxically, internationalism, peace and friendship between nations were also promoted, as well as an image of a state in which "national unity" takes place (this surely referred to the Polish nation). The groups of other nationalities which stayed in Poland would be welcome if they assimilated and did not disturb the image of "national unity".

The events taking place in the next years confirmed the viability of this state-national ideology. In different circumstances, in the 1950s and later many Poles came back to their Homeland - among other places, from the USSR (dispersed in various republics, they often did not know about repatriation possibilities or they were unable to go through the formal requirements). On a very small scale, this process is still going on.

Simultaneously, the relations with Germany (from the Federal Republic) were changing. In the 1960s, Polish bishops wrote a significant letter to bishops in West Germany with the words of forgiveness and an appeal to forgive the tragedies of the past. In the 1970s, the international relations changed for the better. In compliance with the signed agreement and some benefits for Poland, the consent for emigrating to West Germany was granted to people of German nationality or people able to prove their kinship to Germans. Many people left Poland, sometimes with rather illusory formal foundations but in hope for better living standards.

Also Jews, who survived the war but could not or did not want to survive the anti-Jewish movements (including the events in 1967-1968), were leaving Poland.

Over the time, an apparently more and more open state, establishing numerous contacts and broadening its liberties (which was interrupted by the martial law in 1981-1982), was gradually becoming a national state - ideologically, a state of one nation. This is another paradox - in a short time, a country (and its nation/society), which suffered from the aggression of the supporters of a national state, became a national state itself. It is not the only case in the contemporary history, but in the history of this centuries-long multinational and multicultural state, this seems odd. 
In spite of all this, the communities of national minorities and ethnic groups made efforts to maintain their own cultures. Depending on political conditions - the interchanging periods of political "thaws" and "freezes", various cultural associations, groups and centres came into being or vanished. There were rather façade-like (but also mobilizing) festivals of various cultures and the cultural amateur movement was active. With changing fortune, some of these forms still last. The general European and international legal standards have provided the foundations for the activities that protect national and ethnic cultures of minorities. The question whether the state sufficiently supported this activity can be answered by these communities. Probably, the state had possibilities of better support but sometimes political reasons turned out to be decisive.

\section{From pro-Europeanness and opening to Others to inner conflicts (the Polish-Polish war), outer conflicts (disputes with the European Union about democracy) and intolerance of Others}

The political transformations initiated in 1989 created a new chance for multiculturalism - this time with the contact with many (mostly) European states and societies. In contrast to other societies, Poles were able to change the ruling authorities amicably and to undertake the effort of a thorough transformation of the state's political system. Economic reforms and political problems sometimes required painful solutions. Yet, the vast majority of the society could see the aim and sense of the undertaken activities.

What became an important developmental prospect was the integration with the European Union - a strong bond with the states and societies of the West. The efforts to join the EU were hard and required a lot of work and sometimes even sacrifice, including the overcoming of many existential problems. This is frequently forgotten today. The effort payed back and resulted in a success. In 2004, Poland became a member state of the EU.

The new situation opened numerous possibilities of cooperation in almost any field of life. Contacts between people and institutions were established. The state mostly of one nation - the nation that for years experienced various limitations in contacts with the World - opened to Others. Poland became a destination for foreigners, who came here to work, study, rest, etc. Over the time, some possibilities of working and studying in other countries opened to Poles. Poland and Poles became the biggest beneficiary of European funds. Hostile neighbours did not threaten Poland any longer. Germany was an ally. 
The improving (since 1960s and 1970s) relations with this country got a new form - the stereotype of a German-enemy, a "bad German", disappeared. This was an important change. The relations with Ukraine also improved - especially since the Euromaidan events. Poland was becoming a multinational state in a new way - although it remained national in many aspects (e.g. the dominating nationality, culture, religion), it joined the multinationally collaborating European community.

Unfortunately, the political conflict was increasing. Already in the 1990s, the "Solidarity" and post-solidarity environments got more and more conflicted. The arguments were going on about the contribution to the political transformations, methods and evaluations of the ways of acting in the past, the accusations were repeated concerning the peaceful transformation accepted in the "round table" debates. The accusations mostly addressed Lech Wałęsa and later the pro-European current in the new establishment. What became a tragic reason for the division into "two Polands" was the airplane crash in Smoleńsk. The President, the twin-brother of the current leader of the ruling party, died there, as well as 90 other people. There were more and more accusations and libels. The political environment fed itself with conflicts and hatred of many people. This caused serious divisions among citizens.

Both these issues and some other events or motives have contributed to the success of a Eurosceptical party (and ideologically a party supporting a national state) in parliamentary elections. In a new form and in new circumstances, the concept promoted in the interwar period rejuvenated. For several years, the rule has been in the hands of a party which even did not get the majority of votes in the elections but gained the rule owing to the electoral system promoting those who got the biggest number of votes. The reality of the socio-political life in contemporary Poland is well-known in Europe. The fundamental principles of democracy are undermined and the ruling party does not take into account other environments than those which favour the authorities. The situation can be largely described as a façade democracy, earlier quoted in reference to the political system during the dictatorship years in the $2^{\text {nd }}$ Republic of Poland. As a state, Poland is often conflicted with the European Union (e.g. in the issues of breaking democratic principles) and sometimes with particular countries. In the international arena, some artificial superpower-like gestures and clumsiness are frequent.

All this creates an unfavourable climate for any Others. There is no will to receive immigrants, no tolerance for people of different worldviews, what appears is racist, homophobic and xenophobic behaviour. This situation can be 
summarized by the results of the ILGA-Europe ranking. The author, a journalist of a Catholic weekly, says: "Poland is the homophobic leader of the European Union - it is the last in the ILGA-Europe ranking". She continues: "The results are based on the analysis of legislation in particular countries and of the practice of using the law in six categories: equality and ban of discrimination; family; freedom of assembly, association and expression; hate crime and hate speech; gender recognition and corporal integrity; right of asylum. The results are provided as percentages: the leader in equality has been Malta (89\%) for the fourth time, followed by Belgium and Luxembourg (73\%) and then by Denmark and Norway (68\%). Poland: $16 \%$. It is even worse than in previous years when we were last but one" (Burda, 2020).

As regards the court system, the Court of Justice of the European Union intervenes, some judges are harassed for their independent conduct, public (media) witch-hunt is going on aimed at people who criticise the authorities' activity. Nazi manifestations are not rare. What can be also mentioned are the cases of intolerance, chauvinism combined with nationalism, xenophobia, stigmatization, anti-Semitism (Czykwin, 2000; Nikitorowicz, 2012 at al.). Aggression towards the Asian has appeared recently, as they are considered the perpetrators of the current pandemic, as well as towards doctors and other medical staff, who are accused of spreading the virus.

The contemporary socio-political conditions, legal regulations and the economic state enhance migration within the EU and outside it. This contributes to settling down in Poland and in many other states. At the same time, there are communities of various nationalities who have lived in Poland even for ages in some cases. However, the latest national census shows even a stronger domination in size of the people of Polish nationality.

In the 2011 census, there was a choice of two identifications. Regardless of the number and order of the provided declarations, altogether the following identifications were chosen:

Table 3. National-ethnic identification of people comprised in the national census in 2011

\begin{tabular}{|l|c|}
\hline \multicolumn{1}{|c|}{ National-ethnic identification } & $\begin{array}{c}\text { Total - regardless of the number and order } \\
\text { in declarations (in thousands) }\end{array}$ \\
\hline Total & 38511.8 \\
\hline Polish & 37399.7 \\
\hline Total other than Polish & 1467.7 \\
\hline Silesian & 846.7 \\
\hline Kashubian & 232.5 \\
\hline German & 147.8 \\
\hline
\end{tabular}




\begin{tabular}{|l|c|}
\hline Ukrainian & 51.0 \\
\hline Belarussian & 46.8 \\
\hline Roma & 17.0 \\
\hline Russian & 13.0 \\
\hline American & 11.8 \\
\hline English & 10.5 \\
\hline Lemko & 10.5 \\
\hline Italian & 8.6 \\
\hline French & 8.0 \\
\hline Lithuanian & 7.9 \\
\hline Jewish & 7.5 \\
\hline Spanish & 4.0 \\
\hline Vietnamese & 4.0 \\
\hline Dutch & 3.9 \\
\hline Greek & 3.6 \\
\hline Armenian & 3.6 \\
\hline Czech & 3.4 \\
\hline Slovak & 3.2 \\
\hline Kocievian & 3.1 \\
\hline other & 64.4 \\
\hline No identification & 0.4 \\
\hline Unrecognized identification & 521.5 \\
\hline
\end{tabular}

Source: Narodowy Spis Powszechny Ludności i Mieszkań 2011 [National Population and Housing Census 2011], Warszawa 2015, GUS.

Polish nationality was declared by $96 \%$ of the people included in the census. Two biggest communities out of the non-Polish nationalities were the people declaring themselves as Silesians and Kashubians. The majority in both groups (especially Kashubians) simultaneously identify themselves as Poles. Ethnic identifications confirm the revival of these groups' identities, the vitality of their languages and traditions, as well as their focus on emphasizing their ethnic and cultural separateness (sometimes even obtaining some autonomy). These are phenomena that take place in various countries.

Substantially large national minorities are Germans, Ukrainians and Belarussians, although the size of these groups is much smaller than in previous censuses.

Taking into account the results of national censuses, it can be said that Poland is a country in which one nationality distinctly prevails. After 1945, it became an essentially national state. The process of that specific national homogenization - at first resulting from the changes of borders and migration of population - started in the political system defined as socialistic and 
intensified in a different one, as a result of different phenomena (such as assimilation and migration), some demographic reasons or the fact of not providing self-identifications.

Comparing the processes taking place in Poland to those in other countries, it can be noticed that, as regards the issues of multinationalism and multiculturalism, the transformations in Poland have rather a weak and superficial relation to the transformations in other countries, e.g. of the so called "old" EU. Whereas the societies in those states are or are becoming multinational and multicultural (Lewowicki, 2012 and other works), for many (both historical and multicultural) reasons, in the country situated on the Vistula, the multinational state (in the earlier form of unequitable nations) ceased to exist over two hundred years ago and a new multinational and multicultural democratic state has not come into being. The reactions to the waving pro- and disintegration trends in Europe seem different as well (Lewowicki, 2013). The phenomena observed in the EU necessitate the search for better integrating solutions, but politicians in Poland seem to be more engaged in criticism but also in the simultaneous use of union funds. Their efforts and participation in solidarity or pro-ecology projects do not appear very convincing.

The dominating social climate, promoted politics and various determinants of life s4ituations affect education, culture, perception of one's own and others' identity and many other issues. The above outlined image of experiences concerning multinationalism and multiculturalism has influenced the situation of education.

\section{Multicultural education - struggling for identity}

The phenomenon of multiculturalism gained special significance in the $19^{\text {th }}$ century. The above discussed surges of independence movements, social and economic changes that trigger emancipatory tendencies, the years of Napoleonic wars, the Spring of Nations, some signs of educational liberalization in the greatest European monarchies (e.g. legal solutions and actions aimed at the popularization of school education) created a situation in which culture (including languages) of different communities - and in consequence the matters of national identity - were becoming important social issues. This was reflected in education. What occurred both in the countries which came into being then (often with a very short history) and in multinational monarchies were the references to history, culture and languages of particular 
nations. Sometimes, these references were purposefully avoided or history was presented in a biased way, not reflecting the facts.

In the case of Polish territories under the partitions, the approach of the foreign occupiers to the Polish language and culture was not friendly. In the early $20^{\text {th }}$ century, some attempts were made to specify the educational ideology pertaining to minority groups. Paradoxically, in Prussia - the basic tasks of school associated with the education for learners using foreign languages were formulated. They concerned mostly the education of Polish children from the Prussian partition and from the Ruhr area, who had come there with their families as a result of the so called Ostflucht - the outflow of labour force from the Eastern territories. In 1901, those tasks were presented by J. Lichte, who later published them in the journal "Erziehung und Unterricht" (Lichte, 1901).

As M.S. Szymański, a Polish author, summarizes Lichte's text, "three main tasks were indicated for school in regard to the presence of foreign language learners. Firstly, to ensure effective implementation of educational goals, the number of learners in a class should be substantially reduced; secondly, as the Polish population makes a lot of trouble to the German authorities, the priority should be granted to education in the German language with special focus on the geography and history of Germany; and thirdly, in the territories inhabited by »a high percentage of the foreign language element«, special efforts should be undertaken so that Polish children could acquire for their whole life »the German spirit, German feeling, thinking and speaking «" (Szymański, 1995).

By fulfilling these tasks, school will become "an important factor in the general activity aimed at maintaining and disseminating the German national spirit" (ibid.). The aforementioned tasks unambiguously specify the duty of germanization and should lead to the assimilation of minority groups (Poles in this case).

The assimilation of Polish population was also an educational goal in the Russian partition. The initial, relatively mild rule was followed by the years of merciless russification.

The most liberal conditions in education were in the Austrian/AustrianHungarian partition. In this multinational and multicultural monarchy, some forms of national cultures were preserved. Some elements of the language and culture of the nations that composed the state population were allowed also at school. In comparison to the other partitions, this was a more friendly form of assimilation. 
However, until World War I, the examples of organized mass school education for national minorities living in the territories of pre-partition Poland can hardly be found. This does not that mean there were no efforts to have such education. For instance, in the Austrian partition during the Spring of Nations, "on the $19^{\text {th }}$ of April, the Emperor was asked to take care of the Ukrainian population persecuted by Poles, and on the $2^{\text {nd }}$ of May 1848, the Supreme Ruthenian Council, headed by Bishop Grzegorz Jachimowicz, was founded in Lviv. Its demands pertained to the improvement of the national existence "in a constitutional way", the introduction of the Ukrainian language to schools, providing access for Ukrainians to state positions and the same rights for Uniate priests as for Roman-Catholic clergy" (Serczyk, 2009, p. 187).

This demand of the 2.3 million Ukrainian population of Eastern Galicia (Bukovina, Zakarpattia), as well as the agreement established during The Prague Slavic Congress in 1848, turned out to be inefficient in regard to equality of the Ukrainian language (ibid., p. 188).

Belarussian education was an object of interest for the Russian, German and Polish authorities in the early $20^{\text {th }}$ century (Siemakowicz, 1997), but what draws attention is the opinion of Jerzy Turonek, an author of many works on Belarussian school education. He says that the beginning of this education in the region of Białystok is associated with the German occupation during World War I (cf. Matus, Charytoniuk-Michiej, 2013; J. Turonek, 2008). It is thought that this was enhanced by the directives of German authorities that education should be conducted in native languages. The implementation was determined by local authorities and communities.

What came into being as a result of this were: the teacher college in Svislach, Belarussian secondary schools (gymnasiums) in Vilnius and Budslau and several hundreds of the so called people's schools (ibid.). The latter existed only for two or three years but they made people aware that the Belarussian language can help in both home contacts and the acquisition of school knowledge (ibid.).

Coming back to education and culture in the Ukrainian language, it is worth reminding that in 1867 the autonomy of Galicia was proclaimed, which gave some opportunities for the development of national Ukrainian culture and education. Although the chair of Ukrainian literature was founded at the university in Lviv and the Ruthenian Educational Society, until World War I - a lot of effort was made to develop Ukrainian school education and obtain equal rights for the Ukrainian language. The outcomes were rather poor - at the beginning of the $20^{\text {th }}$ century in Eastern Galicia, there were 
only 5 gymnasiums with Ukrainian as the teaching language and not a single real school (Realschule) or teacher college (Serczyk, 2009, p. 243). During the world war after the Russian aggression, at first schools were closed and then opened and run "in compliance with the Russian models and with Russian as the teaching language. In private schools, the Polish language was allowed in a very narrow scope, whereas Ukrainian was to be totally eliminated from schools" (Serczyk, 2009, p. 246). Alongside some war events and political changes, the rise of Ukrainian gymnasiums was allowed.

\section{Educational policy of assimilation - 1918-1939}

After the regaining of independence by Poland, the international standards imposed the duty of elementary education and the possibility to maintain education for minorities in their native language. In 1919, the act on obligatory education for children aged 7-13 (regardless of their nationality and religion) was introduced in Poland.

"Rocznik Statystyki Rzeczypospolitej Polskiej [Statistical Yearbook of the Republic of Poland]" of 1925, which also comprises the results of the 1921 national census, presents the data on school education of various levels in regard to the teaching language or (in the case of higher education) the native language. These statistics show the share of students of different nationalities in education. These are some selected data (concerning the school year $1922 / 23$ or $1923 / 24)$ :

In Poland in 1922/23, there were 26653 public primary schools - including 2272 in towns and 24381 in rural communes. Most of the schools had Polish as the teaching language - 21 996. Other teaching languages were the following: Ruthenian (in 2996 schools), German (in 1 102), Polish and German (in 333), Lithuanian (in 53, including 1 school with both Polish and Lithuanian), Czech (in 42, including 3 schools with both Polish and Czech), Polish and Ruthenian (in 39), Belarussian (in 32), Russian (in 9) and Polish and Jewish (in 1 school).

Moreover, in that school year there were private schools. There, the teaching languages were: Polish (in 350 schools), German (in 115), Jewish (in 113), Hebrew (in 71), Lithuanian (in 40), Ruthenian (in 29), Jewish and Hebrew (in 6), Polish and Hebrew (in 3), Russian (in 2), Polish and Jewish (in 2). There were 731 private schools in total.

The largest nationality groups (Polish, Ruthenian, Jewish and German) had the biggest number of schools with their own teaching language - Jewish 
communities mostly educated children in private schools. Much worse possibilities were offered to the Belarussian community. It should be mentioned here that the authorities at that time refrained from organizing education with Belarussian as the teaching language in the region of Białystok, justifying this with the fact that at the Versailles conference several counties of the Białystok voivodeship (the counties situated to the West of the Curzon Line) had been included into the Polish ethnic territory (Matus, CharytoniukMichiej, 2013).

As regards the number of learners, obviously - the most were educated in Polish (2 642753 learners), whereas 339941 were educated in Ruthenian, 83608 in German, 51221 in both Polish and German, 6245 both in Polish and Ruthenian 2661 in Lithuanian, 1972 in Czech, 1884 in Belarussian, 1450 in Russian, and 339 learners in both Polish and Jewish. The data pertain to state primary schools. The yearbook does not provide information on the number of learners in private schools.

In the school year $1921 / 22$, there were 726 secondary general education schools, in 1922/23 - 762, and in 1923/24 - 764. In 1923/24, the teaching language was: Polish - in 663 schools, Ruthenian - in 20, both Polish and Ruthenian - in 1, Belarussian - in 2, German - in 34, both Polish and German - in 9, Russian - in 10, both Polish and Russian - in 5, both Belarussian and Russian - in 1, Lithuanian - in 1. French - in 2, Jewish - in 6, both Polish and Jewish - in 1, Polish, Russian and Jewish - in 1, Hebrew - in 7, both Polish and Hebrew - in 1 school. Only the schools with Polish, Polish and Ruthenian, German, Polish and German, and Ruthenian were state-run (some were also private or run by local governments). The status of the rest was private.

University students declared the following native languages: Polish 91.3\%, Ruthenian $-1.8 \%$, Belarussian $-0.1 \%$, German $-0.1 \%$, Russian $0.6 \%$, Bulgarian $-0.2 \%$, Yugoslavian $-0.2 \%$, Romanian $-0.1 \%$, Jewish $-5.1 \%$. There were also several Lithuanians (0.0\%) and a group of "others" (including the students of the Trade Academy and the Free Polish University, whose native languages are not provided) - 0.5\% ("Rocznik Statystyki Rzeczypospolitej Polskiej", 1925, pp. 219-221, 224 and 239).

In the previous parts of this study, the heading of the Polish authorities for the assimilation of non-Polish population has been mentioned. Its first symptoms can be seen in statistics - refraining from the organization of school education for Belarussians in some areas of the Białystok region, increasing the number of schools educating in Polish (e.g. in the school year 1923/24, 
there were 427 such schools more), increasing the number of schools with both Polish and Ruthenian (from 89 to 145) with a simultaneous reduction in the number of schools educating just in one language, for instance Ruthenian, German or Czech. Secondary education did not enhance education of minorities either. Therefore, it is not a surprise that $91 \%$ of university students declared Polish as their native language (Poles were $69.2 \%$ of the population of Poland at that time). The nationality composition of secondary school and university students was a delayed effect of the earlier history and educational pathways in the reborn Poland.

The violent war years, revolutions in Germany and Russia, later conflicts about post-war borders of states and the ongoing armed conflicts created a turbulent socio-political climate. On the one hand, e.g. the pursuit of Ukrainians and Belarussians of their own states comprising the whole population of these nationalities grew in intensity, but on the other - the actions of Polish authorities (and of other countries as well) radicalized in their soothing the moods, taking control over the situation and including the national minorities to the society.

The state policy on school education for national minorities was largely subordinated to the idea of national state. This education was maintained, but its activity was reduced and many schools were liquidated (mostly for Belarussians and Ukrainians/Ruthenians). For instance, in the first half of the 1930s, several gymnasiums and one college for Belarussian youth were closed (Matus, Charytoniuk-Michiej, 2013; cf. also: Romanowska, 2010; Siemakowicz, 1998, 1999a, 1999b; Turonek, 2008).

In the voivodeships with a large number of Ukrainian inhabitants, there were many assassinations, sabotage actions (e.g. in 1922 - as a protest against the parliamentary elections), manifestations, attacks. Terrorist activities were conducted by Ukrainian nationalists, who demanded the foundation of "selfexisting Ukraine" that would comprise also the part of Ukraine within the borders of Poland. This activity was supported, among other things, due to the assimilation policy of the Polish authorities towards people of Ukrainian nationality and due to the effects of the crisis.

The assimilation policy was manifested in the act of 1924 on founding bilingual (Polish-Ukrainian and Polish-Belarussian) schools. Its implementation resulted in a substantial reduction of the number of primary schools with Ukrainian as the teaching language. The scale of this liquidation was severe as in 5 years the number of schools was reduced from 2151 to 716 (Serczyk, 2009, p. 324). More or less at the same time, terrorism grew in force. For 
instance, "Nationalists' terrorist attacks comprised almost the whole territory of former Eastern Galicia. From July to November 1930, over 2000 sabotage acts or assassinations aimed at Polish landowners or representatives of the authorities took place. The properties of newcomers were destroyed with particular fierce. Ukrainian peasants took part in this. The main role here was played by the feeling of harm, even more enhanced by irresponsible nationalist politicians" (ibid., p. 326). The response came in the form of pacification actions carried out by the army and police. Several hundred punitive expeditions were conducted and the pacification comprised 16 counties and 450 villages. It can be considered to be another undeclared war. What took place - earlier and later - were armed conflicts, terrorist actions, retributive pacifications, but also the struggle for education. Ukrainians demanded education with Ukrainian as the teaching language, while the Polish educational authorities kept liquidating such schools, claiming that there were not enough qualified teachers, not enough coursebooks and the quality of teaching was poor. At the same time, work in such schools was not aided, there were not teacher colleges preparing for education in Ukrainian, not much effort was made to prepare didactic aids, etc.

The fate of schools for the Slovak national minority turned out to be hard as well. In 1920 (by the decision of the Conference of Ambassadors), 14 residence places where Slovaks had lived for centuries in Spiš and 12 in Orava were included into Poland. There were Slovak schools, functioning within the school system of Austria-Hungary. Despite hungarization (those places were located in the area called Upper Hungary), Slovak teachers worked there. After including those Spiš and Orava places into Poland, Slovak schools were transformed into Polish and most of Slovak teachers gave up their jobs. The authors representing Slovak environments state that Slovak education (education with Slovak as the teaching language) ceased to exist in the Southern borderland of Poland (Majerikova, 2009; Juchniewiczová, 2013). This is confirmed by the lack of information on schools educating in Slovak in "Rocznik Statystyki Rzeczypospolitej Polskiej" of 1925.

According to the same source, in the first half of the 1920s there were primary schools with Czech as the teaching language. In the school year $1922 / 23$, there were 42 such schools (including 3 with both Polish and Czech), which is mentioned earlier. Yet, a year later, there were only 32 such schools and all of them had two teaching languages - Polish and Czech. The school in Zelów (now in the Łódź voivodeship) was not included in the statistics. It started in 1807 as an elementary religious school organized by 
Protestants. The changing fate of this school and the community of Zelów have been described in many publications (cf. Pospiszył, 2013; as well as: Papuga, Gramsz, 2003; Tobrański, 1994). It is worth mentioning here that in the 1920s Czech denominational schools functioned at parishes/congregations. In one of them Czech was the teaching language. What seems interesting is that the schools educating in Czech, later in Polish and Czech, which were included in the statistics, were located in the Volhynia voivodeship (only one was in the Poznan voivodeship).

In the administrative district of Vilnius, in 1922/23, there were 52 schools with Lithuanian as the teaching language and in 1923/24 - 31 elementary state schools, as well as respectively in the same years -40 and 34 private schools. Moreover, there was one state school in the Białystok voivodeship, and 1 private secondary school conducted education also in the Lithuanian language.

The above quoted data clearly confirm the limitation of schools in which the only teaching language was the one of a minority community. As it can be read in the statistics, the number of schools with two teaching languages (Polish and the one of a different national group) grew fast from year to year. Over the time, some schools with a non-Polish teaching language (even if it co-occurred with Polish) were closed or transformed into schools educating only in Polish. Education in the languages of minorities was rightly treated as an important factor of shaping and preserving the national identity of nonPolish population. Compliantly with the increasingly dominating ideology of national state, it was considered that such influences should be limited and, therefore, many restrictions were introduced. This was particularly severe in the eastern borderlands. In the struggle for the identity - the assimilation with the Polish majority or the preservation of language and culture (the identification with another national group), the state used school education as a way to accelerate assimilation. With over a hundred years of experiences of russification and germanization during the partitions and in spite of the lasting of the Polish identity, politicians and a part of the Polish society applied such a way of reconstructing the state and society.

\section{The war years - 1939-1944/1945}

The situation of school education during World War II was different and changeable in particular regions. In the Eastern territories, at first overtaken by the Soviet Russia, the occupiers' system of education was introduced. 
Later - after overtaking that area by Germans - teaching in different languages was allowed but depended on the occupiers' decisions (e.g. municipality commissaries), the standpoint of local communities, the condition of teaching staff, the availability of coursebooks, etc. (cf. Matus, CharytoniukMichiej, 2013). Temporarily, Germans allowed educational solutions that enhanced the favour of local inhabitants (e.g. in Ukraine). Slovaks were educated in Slovak schools, after attaching Spiš and Orava to the Slovak state (Juchniewiczová, 2013). Czech children either did not have school education or attended German schools (especially if children's parents had signed the German nationality list) (Pospiszył, 2013). Obviously, Germans used German schools. Jews were deprived of education and largely also of their life. Apart from the form of school education permitted by the occupiers, educational activity of Poles and a part of non-Polish population took place as secret teaching and learning. This is a well-known issue, which goes far beyond multicultural education conducted by the Polish state. Therefore, the motifs of school education in the years of World War II and the occupation of Poland will not be developed there.

\section{Policy of national unity - a continuation of assimilation. 1945-1989}

In the reborn Poland, within its new borders, there were much fewer people of non-Polish nationality than in the years of the II Republic of Poland (1918-1939). Although the earlier quoted National Census of 1946 did not reveal this, among Polish citizens, there were still Belarussians, Ukrainians, Germans, Lithuanians, Slovaks, etc. The size of these nationality groups got largely reduced. The smallest changes took place in the case of Slovaks, who lived in Spiš and Orava within Poland until 1939, then during the war in Slovakia, and after the end of the war - in Poland again. Each national minority wanted to have schools educating in their own native language.

The sources referring to school education in the first post-war years usually convey a message suggesting some difficulties in the reconstruction, creation, and later activity, of education for national minorities. These are some examples:

The first two primary schools with Slovak as the teaching language were founded in 1947. Three years later, there were 33. In the 1950s, there was the biggest number of such schools or schools with the additional teaching of this language. Schools educating in Slovak prevailed, yet it changed for the 
worse in the late 1960s, when schools with Slovak as an additional language outnumbered them. From 1975, only 2 schools educated in Slovak. Among other things, the reason for such a reduction was the shortage of Slovakspeaking teachers (Juchniewiczová, 2013) and better availability of a network of schools educating in Polish (which is of due significance in the mountainous conditions).

Schools with Belarussian as the teaching or additional language started in 1944. Apart from primary schools, there were 3 secondary schools (1 lower and 1 higher). The early start did not bring success, because: "From the school year 1945/46, the educational authorities started the liquidation of Belarussian education, justifying this with Belarussians' leaving Poland, the softening of national antagonisms, and a low quality of teaching in those schools (unqualified staff, lack of didactic materials). The activity of county education inspectorates led to almost complete elimination of Belarussian education in the school year 1947/48" (Turonek, 2008; Matus, CharytoniukMichiej, 2013, p. 40). The next political decision enabled education in Belarussian or its introduction as a school subject from 1949 (ibid.).

The political events in the 1950s resulted in a decrease in the number of schools with the Belarussian language (cf. Mironowicz, 1994; quoted in: Matus, Charytoniuk-Michiej, 2013). Over the time, Belarussian was treated as an optional subject. In the 1970s, the educational reform - the liquidation of small rural schools - contributed to another reduction in the number of schools with Belarussian as the teaching or optional language. The number of students learning this language substantially decreased. In 1955-1970, there were about 10-11 thousand such learners, in the 1970s and 1980s - about 3.9-4.5 thousand (Turonek, 2008, p. 767; Romanowska, 2010, pp. 99-101; quoted in: Matus, Charytoniuk-Michiej, 2013, p. 43). School education with the Belarussian language comprised increasingly fewer learners.

The fate of school education with Ukrainian as the teaching language was even harder. Dispersed after the "Wisła [Vistula]" action, Ukrainians usually inhabited small villages, in which they constituted a distinct minority (less than $10 \%$ on average). They were deprived of possibility to learn Ukrainian. The so called points of teaching the Ukrainian language came into being only in 1952. They were cross-school and cross-class teams of children at various age. In 1956, there were 140 such points. Primary and secondary schools with the Ukrainian language were organized as well (Łabowicz, 2013). "The best period in the development of Ukrainian school education was the late 1950s and the 1960s. In 1963/64, 3283 learners were taught Ukrainian in 7 schools 
and 137 points, which was the most in the whole history of teaching Ukrainian in the Polish People's Republic" (Łabowicz, 2013, p. 79).

In the 1970s, a regress in the education of Ukrainian took place. This breakdown was caused, among other reasons, by the reform of the school system and the already mentioned liquidation of small rural schools and teachers colleges (preparing teachers for schools with Ukrainian), as well as by anti-Ukrainian propaganda (resulting in hiding the national identity). The number of learners considerably decreased in the 1970s and 1980s (ibid., pp. 79-80). The smallest number of learners and teaching points was in the school year 1981/82. In 1988/89, during the political breakthrough, there were 4 schools and 57 points of teaching, which altogether comprised 1410 learners (cf. the table in: Syrnyk, 2006; presented in: Łabowicz, 2013, p. 80).

The situation of the German national minority was particularly unfavourable. Bernard Gaida, the author of a study on teaching German as a national minority language in Poland, the head of the Association of German Sociocultural Societies, reminded his readers in his text of 2013 of the total ban on "teaching the German language in Upper Silesia and Warmia and Masuria throughout the whole time of the Polish People's Republic" (Gaida, 2013).

The first post-war years were not a favourable time for school education with the Lithuanian language. Schools in Puńsk and Sejny were opened only in 1952. In the following years, the number of schools with Lithuanian as the teaching language grew to 9, and in 15 schools this language was treated as additional. Those schools had serious difficulties, including the lack of teachers who knew Lithuanian and coursebooks in this language (Wojciechowski, 2013). In 1956, a secondary general education school was founded in Puńsk. Soon, it distinguished itself by a high quality of teaching and educational successes. Despite a lot of effort, at that time founding such a school in Sejny - a traditional centre of activity of the Lithuanian community - was not possible (ibid.).

The history of school education for national minorities in 1944-1989 although taking place in different political conditions, in different relations with neighbouring countries, in different times - to a certain extent seem to be a continuation, another stage, of the social processes in the II Republic of Poland. Paradoxically, what has turned out to dominate in various political systems and constellations is the ideology of national state. This has happened in a country in which many citizens appeal to the tradition of a multinational, multicultural, tolerant country that is friendly to Others. This image of the past was often embellished and considered true by some and false by 
others. There were reasons for cherishing this positive impression and referring to it. However, it turned out that what dominated - at first after many years of partitions and then wars - was the model of the state which was not much friendly to Others who were also its citizens.

The past conflicts (also armed ones), various experiences of war years, politics and propaganda shaped a distrustful and unwilling attitude to national minorities. Without a doubt, people's behaviour and interpersonal relations have always been varied - friendly, indifferent, hostile. In the case of the educational policy, they turned out to be unwilling towards minorities, aiming at their assimilation, limiting the possibilities of cherishing their language and culture. To a certain extent, this educational policy was successful - schools for minorities were closed and new ones were not organized, the number decreased of children who learned their native language, history and culture. Some really submitted themselves to assimilation. It is hard to accept that - in the society with a long tradition of struggle for preserving the Polish identity - the attitudes enhancing the loss of identity by the co-citizens of a different nationality are right and bring a success worth recognition.

\section{After 1989 - multicultural or/and intercultural education}

The widely consolidated model of multicultural education assumes that national minorities have schools dedicated to them and focus on learning the language, history and culture of their own nation or ethnic group. The history of multicultural education in this sense has been a continuous struggle between minority and majority communities. Equipped with proper instruments of rule, the majority usually has an advantage and tries to make use of it. The above presented examples seem to confirm this.

A lot of effort is undertaken not to allow uneven fights. Widely known international legal regulations indicate standards in the issues of education and culture of national and ethnic minorities. In practice, even ratified agreements are often not obeyed or the conditions are created which hinder the use of rights granted to minorities.

The political transformations, initiated in Poland in 1989, brought hopes for beneficial changes. Partially, they were fulfilled. For instance, children of Lithuanian nationality got the possibility to learn in their language in the classes with Lithuanian as the teaching language in two schools in Sejny and later the School Complex with Lithuanian Teaching Language came into being. Yet, problems started soon - the educational reform posed a threat 
of liquidation, several schools were later really closed. As a result, 50\% of schools with Lithuanian as the teaching language or with the possibility to learn it were liquidated (Wojciechowski, 2013, pp. 25-28). Owing to the efforts of the Lithuanian community and substantial support of the Lithuanian government, the school in Sejny came into being. The access to coursebooks in Lithuanian improved as well (ibid., pp. 29-33). Currently, there are several schools with Lithuanian as the teaching language or with the possibility to learn it in cross-class teams. The schools are largely supported by the Lithuanian government.

A certain progress has been made as regards education in Belarussian. A kindergarten was founded with classes in the Belarussian language and on Belarussian culture, this language is taught as a subject in over 20 schools. The lasting of Belarussian education and culture largely results from the social activities of people of this nationality.

Ukrainian school education is in a similar situation. After the political transformation there were from 4 to 8 (in the school year 1995/96) schools with Ukrainian as the teaching language and 5 in the following years (Syrnyk, 2006; quoted in; Łabowicz, 2013). That number has maintained for many years. Moreover, there are over 100 teaching points. Later statistics are not reliable as regards education, because they provide one number for both schools and teaching points. What still dominates are cross-class, crossgroup and cross-school teaching points. The schools and teaching points are scattered, which results from the dispersion of Ukrainian population after the (earlier mentioned) post-war "Wisła [Vistula]" action. Education in teaching points is often ineffective - hindered by small lesson assignment for this education, the need to commute to the points, the lack of curricula and proper coursebooks, lack of methodological support for teachers (cf. Łabowicz, 2013). What seems helpful are the contacts with schools in Ukraine. It seems the quoted author is right in her opinion that: "[...] the future of Ukrainian education in Poland will largely depend on the condition of the Ukrainian community. Without a doubt, this will be influenced by: the support of the Polish state, breaking the negative stereotype of a Ukrainian, dissemination of the knowledge concerning the Ukrainian minority, and especially by running educational activities at school, as well as building the attitudes of openness and tolerance, etc." (ibid., p. 102).

The German minority has the biggest number of schools and points educating in German. After the period of bans, it was possible to maintain the German language and familiarize with history, geography and various fields 
of culture in the course of school education. In 1992-1998, the advancement of education with the German language was particularly distinct. In the mid2010s, there were about 500 schools in which learning German was possible, though the form of additional lessons prevailed. The German community suggested introducing education in German or in the bilingual system (which would maintain both the German identity and Polish citizenship).

Keeping in mind that the legally recognized national minorities in Poland are: the Belarussian, Czech, Lithuanian, German, Armenian, Russian, Slovak, Ukrainian and Jewish minority, it should be noticed that, apart from the aforementioned schools and teaching points for Belarussians, Lithuanians, Germans and Ukrainians (four largest minorities in Poland), there are also few educational centres for the Slovak, Jewish and Armenian minority.

Among ethnic minorities (the Karaim, Lemko, Roma and Tatar ones), only Lemkos have the possibility of learning their language in schools and teaching points. According to the statistical data, the other groups have no similar possibilities or they use non-typical educational forms or are taught in their own environments.

What seems worth highlighting is the rebirth of the regional language and culture of Kashubians (Kossak-Główczewski, Kożyczkowska, 2013; Kożyczkowska 2019). The Kashubian community has over 400 centres (primary and secondary schools, teaching points) in which the Kashubian language and culture is taught and familiarized with. It should be added here that this community, comprising about 232.5 thousand people - mostly identify with Polish nationality (about 215 thousand people), the Kashubian identification is declared as the second (cf. Narodowy Spis Ludności i Mieszkań, 2015; data concerning 2011. There were two possible identifications).

Another phenomenon worth attention is a relatively numerous identification with the Silesian region - its language and culture. In the 2011 national census, such identification was declared by about 846.7 thousand people, including 430.8 thousand who simultaneously chose the Polish identification. So far, this has not been reflected in the system of school education.

The general image of school education for people of non-Polish nationality does not seem impressive. The possibility of teaching-learning the language and familiarizing with the history and culture of minorities in schools are limited for various reasons. Firstly, they mainly pertain to four national minorities, one ethnic group and one regional language and culture. Secondly, the dominating form is education in teaching points - with small number of teaching hours, in a narrow thematic scope and often in difficult condi- 
tions. The state of this part of the educational system largely depends on the minority communities and, what can be easily seen, on the support of their homeland.

Generally, what is not considered in school education for national or ethnic minorities and for groups distinguished by their regional language and culture are the possibilities to learn the language and culture in schools and other centres which are available outside the Polish system of education - e.g. in schools at embassies of foreign states. Some educational possibilities are not presented in the statistics in a detailed way. It can be mentioned here that in the 2011 national census, there was only a choice of 23 national identifications, but there were also the categories: "other" (chosen by 64.4 thousand people), "without national belonging" ( 0.4 thousand) and "indefinite" (chosen by about 521.5 thousand people). Some learners in all these groups attend Polish schools, however - some (both from national minorities and communities without the legal status of a national, ethnic or regional minority) are educated in other schools.

What seems necessary while discussing multicultural education is a critical view on the specific paradigm of this education. The care for the possibility to learn in the native language, to familiarize with the history and culture of the community with which one identifies, to preserve important elements of one's identity is well-understood. The education that should serve this aim has been formed in the opposition to the education of dominating groups, oriented towards the assimilation of minority groups (communities) - or rather the dominated groups (frequently larger than the majority group). Communities (sometimes whole societies) have demanded such school education that functions within a particular system of education but, in fact, outside the school education of the dominating community. It has been known for a long time that, apart from the benefits concerning the cherishing of the group and individual identity, this can bring about some phenomena and effects which cannot be regarded as beneficial. These are, for instance: self-stigmatization which enhances stigmatization by the majority group (Czykwin, 2000), xenophobic attitudes, the feeling of alienation in the state of which one is a citizen, consolidation of stereotypes. All this might have turned out to be a necessary price in the condition of particular struggle for identity.

Today, the questions are justified whether the struggle for identity must really go on (or even whether it is going on), whether the comprehension of an identity is still restricted to e.g. one nation or one religion (denomination) 
and whether the preparation for life in the society of a particular country takes place best in, with certain exaggeration, educational isolation - an educational island. The doubts concerning such an approach are noticed, among others, by the earlier quoted authors exploring school education for national minorities in Poland. They feel the need of breaking with stereotypes, of a mutual exchange of the knowledge concerning Others, of dialogue, of fulfilling one's own educational aspirations, but also - as B. Gaida writes - of "shaping the European idea of unity in diversity" (Gaida, 2013, p. 155). It should be added: and following this idea in educational practice.

The traditional, perpetuated for over a hundred years, image of multicultural education has had supporters and implementers in educational practice. Yet, the changing (changed by people) conditions of life and multiculturalism treated in many places of the world - also in Europe and in the EU - as a widely accepted natural phenomenon, as a kind of wealth providing developmental chances, gives new importance to undertaking the dialogue with Others, to applying the attitudes of openness to Others and their cultures, to learning their world (which in many aspects might be a shared world). This becomes more important than isolation, rejection of Others and the pseudopatriotic closing oneself in the somehow defined "own groups".

What enhances the new approach is not so much multicultural education (led "next to" Others, in certain isolation and very often in artificial opposition, with the use of stereotypes and bad memories of the past) but intercultural education.

Intercultural education promoted in Poland is based on numerous foreign experiences which have been aimed at mutual familiarization of people of various cultures, at dialogue, at getting acquainted with the history and cultural wealth of Others (an overview of various educational concepts and practices, among other studies, in: Lewowicki, Ogrodzka-Mazur, SzczurekBoruta, eds, 2000). Practical activities have been inspired e.g. by the Theory of Identity Behaviours (cf. Lewowicki, 1995a, 1995b), the concept of creating a child's identity (Nikitorowicz, 2005), the concept of multidimensional identity (cf. Nikitorowicz, 2001; 2003; many works by Lewowicki - also quoted at the end of this study).

Crucial inspiration has been provided in the works of Mikhail Bakhtin, showing the borderlands of cultures. This substantially broadens the understanding of multiculturalism as a multitude of national or ethnic cultures to a multitude of cultures of people of the same nationality, believers of the same religion, followers of the same ideology, inhabitants of the same home, 
etc. (Witkowski, 2000). Such an approach leads to recognizing the multitude of cultures in various fields of life and liberates from the limitation to the most often noticed national cultures or religions/denominations. In this sense, borderlands of cultures have a universal dimension - they might concern differences between all people and the worlds of their cultures. This obviously comprises national, religious, cultural, regional, micro-environmental, educational and other differences. In the conditions of contemporary Poland (with the society of which 96-97\% declare Polish identity and with the dominating policy of a national state), such a sense given to diversity and borderlands of cultures was a radical turn in the understanding of multiculturalism - traditionally associated with nationality and religion/denomination. Multiculturalism has as if regained its fundamental sense - of a multitude of cultures.

An important change came with recognizing that an identity did not have to be attributed (because of the place and social environment of birth), somehow inherited. With growing frequency, identity is chosen by an individual, changes in self-identification are made. This particularly pertains to cultural identity.

Finally, what takes place in the perception of multiculturalism and identity is the realizing and acceptance of the fact that an identity is shaped in various environments and cultures. Thus, it becomes a multidimensional identity, drawing from such environments (and their cultures) as family, local environment, region, educational institutions and environments, religious/denominational institutions, nation (and in broader terms - society), state, and more and more often the region of the world or the globe in general. What is observed is drifting apart from simplified identifications only with a nation, state or religion/denomination. Obviously, this process of self-identification and identification of other people is still going on and has a lot of significance for people. However, what appears in deeper reflections are much more complex identifications. This was reflected, for instance, in the national and ethnic declarations in the above quoted 2011 national census in Poland.

The discussed issues are manifested in educational practice. Many undertakings in schools and cultural-educational institutions are initiated owing to suggestions from academic environments. It was here - in universities and other institutions of higher education - where the departments and chairs (or other units) dealing with intercultural education were established. Broader interest in this education can be associated with the foundation of the Social Team for Research into Borderland Education and Culture in 1994. Joint 
studies and publications contributed to the birth of research teams in various universities. Over the time, a team was established at the Committee of Pedagogical Sciences of the Polish Academy of Sciences and - later - the Association for Supporting Intercultural Education. The years 1994-2015 turned out to be the "golden age" in the development of intercultural pedagogy as a scientific subdiscipline in Poland. Staff and organizational development took place and many studies were undertaken. Research activity co-occurred with educational initiatives. In schools and cultural-educational institutions, many classes were introduced which enabled the meetings and closer familiarization with - generally speaking - Others and their cultures. The stereotypes and barriers caused by mutual non-acquaintance were broken.

The favourable conditions were created owing to the pro-European policy of the government (consecutive governing staffs) and the efforts to join the European Union. This took place in 2004 and brought about the opening to the EU states, as well as benefits in many spheres of life. Intercultural education became an important field of social practice, helpful in the integration with the union states and societies. To a certain extent, this also brought state school education (for Poles) closer to school education for national minorities. What is more, a lot of interest in many communities (and their cultures) appeared, which so far had remained beyond the official current of education for minorities.

The time of efforts to join the Union and the first years of rightful membership brought about positive experiences in education - intercultural contacts revived, better acquaintance with Others and mutual enriching of cultures became possible. What could be noticed was the youth's aiming at familiarization with foreign cultures (along with their languages) and the conditions of life in the union part of Europe. New perspectives opened, there were expectations in many environments that school would better prepare the young for their future life. Similar expectations were expressed by learners from Polish environments abroad, who were educated in foreign schools with Polish as the teaching language (cf. e.g. Ogrodzka-Mazur, Klajmon-Lech, Różańska, different parts of the world (also some European countries) does not foretell good changes. Therefore, there is even bigger need for efforts to maintain and develop intercultural education, which enhances familiarization with and understanding of Others and their cultures, as well as friendly cooperation and peace. This message encourages or even obligates to collaboration with institutions and people who head for international cooperation, obeying international legal norms, and better living standards. As 
it is believed, education conveys mainly noble messages but it is also known that its causative force is limited. This necessitates the search for allies with whom it is possible to achieve more for a good cause. Paraphrasing the words of John Paul II, it can be said that education in its positive programme serves good use as it helps to elicit from people the best sides of humanity.

\section{Bibliography (referred to and for further study)}

Bonusiak, W. 2007. Historia Polski 1944-89. Rzeszów: Wydawnictwo Uniwersytetu Rzeszowskiego.

Bukowska-Marczak, E. 2019. Przyjaciele, koledzy, wrogowie? Relacje między polskimi, żydowskimi i ukraińskimi studentami Uniwersytetu Jana Kazimierza we Lwowie w okresie międzywojennym (1918-1939). Warszawa: Wydawnictwo Neriton.

Burda, E. 2020. Oblany egzamin z równości. Tygodnik Powszechny. 21 (3698). Czykwin, E. 2000. Białoruska mniejszość narodowa jako grupa stygmatyzowana. Białystok: Wydawnictwo Uniwersyteckie „Trans Humana”.

Davies, N. 2003. Boże igrzysko - historia Polski. Kraków: Wydawnictwo Znak.

Dzwonkowski, R. SAC. 1994. Polacy na dawnych kresach wschodnich. Z problematyki narodowościowej i religijnej. Lublin: Oddział Lubelski Stowarzyszenia „Wspólnota Polska”.

Encyklopedia popularna PWN. 1982. Warszawa: PWN.

Friszke, A. 2020 (from the interview "Marzyciel i realista" for M. Mirowski). Polityka. 21.

Gaida, B. 2013. Nauczanie języka niemieckiego jako języka mniejszości narodowej w Polsce - stan i przyszłość. In: Lewowicki, T., Nikitorowicz, J. and Szczurek-Boruta, A. eds. Szkoły mniejszości narodowych i społeczności kaszubskiej w Polsce - stan, problemy i perspektywy. Warszawa - Cieszyn - Białystok: Wyższa Szkoła Pedagogiczna ZNP, Wydział Etnologii i Nauk o Edukacji Uniwersytetu Śląskiego w Katowicach, Uniwersytet w Białymstoku, Stowarzyszenie Wspierania Edukacji Międzykulturowej, pp. 151-155.

Gajdzica (Szafrańska), A., Piechaczek-Ogierman, G. and Hruzd-Matuszczyk, A. 2014. Edukacja postrzegana z perspektywy uczniów, rodziców i nauczycieli ze szkót z polskim językiem nauczania w wybranych krajach europejskich. Cieszyn - Toruń: UŚ, Wydawnictwo Adam Marszałek.

Giddens, A. 2007. Nowoczesność i tożsamość. „Ja” i społeczeństwo w epoce późnej nowoczesności. Warszawa: PWN. 
Główny Urząd Statystyczny Rzeczypospolitej Polskiej. 1925. Rocznik Statystyki Rzeczypospolitej Polskiej. Warszawa: GUS.

Grabowska, B. 2013. Poczucie tożsamości młodzieży uczacej się w szkołach $z$ polskim językiem nauczania na Białorusi, Ukrainie i w Republice Czeskiej - studium porównawcze. Katowice - Toruń: Wydział Etnologii i Nauk o Edukacji Uniwersytetu Śląskiego, Wydawnictwo Adam Marszałek.

Grodecki, R., Zachorowski, S. and Dąbrowski, J. 1995 and further. Dzieje Polski średniowiecznej. Vol. 1 and 2. Kraków: Wydawnictwo Universitas. Juchniewiczová, V. 2013. Szkolnictwo słowackiej mniejszości narodowej w Polsce. In: Lewowicki, T., Nikitorowicz, J. and Szczurek-Boruta, A. eds. Szkoły mniejszości narodowych i społeczności kaszubskiej w Polsce - stan, problemy i perspektywy. Warszawa - Cieszyn - Białystok: Wyższa Szkoła Pedagogiczna ZNP, Wydział Etnologii i Nauk o Edukacji Uniwersytetu Śląskiego w Katowicach, Uniwersytet w Białymstoku, Stowarzyszenie Wspierania Edukacji Międzykulturowej, pp. 105-121.

Kaczmarek, R. 2019. Powstańcza wojna. In: Dzieje Śląska, czyli historia na pograniczu. Polityka. Pomocnik Historyczny. 7.

Kaczmarek, R. 2019. Powstania ślaskie 1919-1920-1921. Nieznana wojna polsko-niemiecka. Kraków: Wydawnictwo Literackie.

Kożyczkowska, A. and Kossak-Główczewski, K. 2013. Edukacja języka i kultury kaszubskiej na terenie Kaszub. Wybrane aspekty. In: Lewowicki, T., Nikitorowicz, J. and Szczurek-Boruta, A. eds. Szkoty dla mniejszości narodowych i społeczności kaszubskiej w Polsce - stan, problemy i perspektywy. Warszawa - Cieszyn - Białystok: Wyższa Szkoła Pedagogiczna ZNP, Wydział Etnologii i Nauk o Edukacji Uniwersytetu Śląskiego w Katowicach, Uniwersytet w Białymstoku, Stowarzyszenie Wspierania Edukacji Międzykulturowej, pp. 159-202.

Kożyczkowska, A. 2019. Kaszubszczyzna. Pedagogicznie o języku i tożsamości. Gdańsk: UG.

Kubiak, H. and Paluch, A.K. eds. 1980. Założenia teorii asymilacji. Wrocław - Warszawa - Kraków - Gdańsk: Zakład Naukowy im. Ossolińskich Wydawnictwo PAN.

Kyuchukov, H., Lewowicki, T. and Ogrodzka-Mazur, E. eds. 2015. Intercultural Education: Concepts, Practice, Problems. Munich: LINCOM Academic Publishers.

Lewowicki, T. 1995a. O badaniach społeczności pogranicza - od parcjalnych opisów ku elementom teorii zachowań tożsamościowych. In: Niki- 
torowicz, J. ed. Edukacja międzykulturowa. W kręgu potrzeb, oczekiwań i stereotypów. Białystok: Wydawnictwo Uniwersyteckie „Trans Humana”. Lewowicki, T. 1995b. Problemy tożsamości narodowej - w poszukiwaniu sposobów uogólnionych ujęć kwestii poczucia tożsamości i zachowań z tym poczuciem związanych. In: Urlińska, M. ed. Edukacja a tożsamość etniczna. Toruń: UMK.

Lewowicki, T., Ogrodzka-Mazur, E. and Szczurek-Boruta, A. eds. 2000. Edukacja międzykulturowa $w$ Polsce i na świecie. Katowice: UŚ.

Lewowicki, T. 2000. W poszukiwaniu modelu edukacji międzykulturowej. In: Lewowicki, T., Ogrodzka-Mazur, E. and Szczurek-Boruta, A. red. Edukacja międzykulturowa w Polsce i na świecie. Katowice: UŚ.

Lewowicki, T. and Ogrodzka-Mazur, E. ed. 2001. W poszukiwaniu teorii przydatnych w badaniach międzykulturowych. Cieszyn: UŚ - Filia w Cieszynie.

Lewowicki, T. and Urban, J. eds. 2002. The Individual in Relation to Others and Other Cultures. Cieszyn: UŚ - Filia w Cieszynie.

Lewowicki, T. and Ogrodzka-Mazur, E. eds. 2006. Polityka społeczna $i$ oświatowa a edukacja międzykulturowa. Cieszyn - Warszawa: UŚ - Filia w Cieszynie, WSP ZNP w Warszawie.

Lewowicki, T., Grabowska, B. and Szczurek-Boruta, A. eds. 2007. Intercultural Education. Theory and Practice. Cieszyn - Warszawa - Toruń: Wydział Etnologii i Nauk o Edukacji Uniwersytetu Śląskiego, WSP ZNP w Warszawie, Wydawnictwo Adam Marszałek.

Lewowicki, T., Ogrodzka-Mazur, E. and Szczurek-Boruta, A. eds. 2011. Edukacja międzykulturowa - dokonania, problemy, perspektywy. Cieszyn Warszawa - Toruń: Wydział Etnologii i Nauk o Edukacji Uniwersytetu Śląskiego, WSP ZNP w Warszawie, Wydawnictwo Adam Marszałek.

Lewowicki, T. 2012a. Edukacja międzykulturowa - bilans otwarcia 2012. Edukacja Międzykulturowa. 1, pp. 15-46.

Lewowicki, T. 2012b. Oświata w warunkach wielokulturowości - od asymilacji do edukacji wielokulturowej i wielowymiarowej tożsamości. In: Kremień, W.G., Lewowicki, T., Nikitorowicz, J. and Sysojewa, S.O. eds. Edukacja w spotecznościach wielokulturowych. Warszawa: WSP ZNP w Warszawie.

Lewowicki, T. 2013a. Edukacja wobec odwiecznych i współczesnych problemów świata - konteksty i wyzwania edukacji międzykulturowej. Edukacja Międzykulturowa. 2, pp. 19-37.

Lewowicki, T., Nikitorowicz, J. and Szczurek-Boruta, A. eds. 2013b. Szkoty 
dla mniejszości narodowych i społeczności kaszubskiej w Polsce - stan, problemy, perspektywy. Warszawa - Cieszyn - Białystok: Wyższa Szkoła Pedagogiczna ZNP w Warszawie, Wydział Etnologii i Nauk o Edukacji Uniwersytetu Śląskiego w Katowicach, Uniwersytet Białostocki, Stowarzyszenie Wspierania Edukacji Międzykulturowej.

Lewowicki, T. 2015. Wielokulturowość i globalizacja a strategie edukacji międzykulturowej. Pogranicze. Studia Społeczne. XXV, pp. 13-24.

Lewowicki, T., Ogrodzka-Mazur., E., Chojnacka-Synaszko, B. and Klajmon -Lech, U. eds. 2018 Spheres of Spiritual Life. A Study on Permanence and Changeability of Identity Behaviors in Borderland Communities. Munich: LINCOM Academic Publishers.

Lichte, J. 1901, Welche Aufgaben erwachsen unserer Schule aus dem Vorhandenseln fremdsprachiger Kinder? Erziehung und Unterricht. H. 21.

Łabowicz, L. 2013 Raport o stanie szkolnictwa ukraińskiego w Polsce. In: Lewowicki, T., Nikitorowicz, J. and Szczurek-Boruta, A. eds. Szkoty dla mniejszości narodowych i społeczności kaszubskiej w Polsce - stan, problemy, perspektywy. Warszawa - Cieszyn - Białystok: Wyższa Szkoła Pedagogiczna ZNP w Warszawie, Wydział Etnologii i Nauk o Edukacji Uniwersytetu Śląskiego w Katowicach, Uniwersytet Białostocki, Stowarzyszenie Wspierania Edukacji Międzykulturowej, pp. 75-104.

Majeriková, M. 2009. Slovenské školstvo v oblasti polıkého Spiša v rokach 1918-1945. In: Lityński, A. red. Państwo, prawo, społeczeństwo w dziejach Europy. Katowice - Kraków: UŚ.

Matus, J. and Charytoniak-Michiej, G. 2013. Szkolnictwo białoruskie w Polsce. In: Lewowicki, T., Nikitorowicz, J. and Szczurek-Boruta, A. eds. Szkoty dla mniejszości narodowych i społeczności kaszubskiej w Polsce - stan, problemy, perspektywy. Warszawa - Cieszyn - Białystok: Wyższa Szkoła Pedagogiczna ZNP w Warszawie, Wydział Etnologii i Nauk o Edukacji Uniwersytetu Śląskiego w Katowicach, Uniwersytet Białostocki, Stowarzyszenie Wspierania Edukacji Międzykulturowej, pp. 35-73.

Mironowicz, E. 2007. Białoruś. Warszawa: UW.

Mironowicz, E. 1994. Polityka władz wobec szkolnictwa białoruskiego na Białostocczyźnie w latach 1944-1980. Białoruskie Zeszyty Historyczne. 2, pp. 65-76.

Narodowy Spis Powszechny Ludności i Mieszkań 2011. 2015. Warszawa: GUS. Nikitorowicz, J. ed. 1995a. Edukacja międzykulturowa. W kręgu potrzeb, oczekiwań $i$ stereotypów. Białystok: Wydawnictwo Uniwersyteckie „Trans Humana”. 
Nikitorowicz, J. 1995b. Pogranicze, tożsamość, edukacja międzykulturowa. Białystok: Wydawnictwo Uniwersyteckie „Trans Humana”.

Nikitorowicz, J. 2001. Wielopłaszczyznowa i ustawicznie kreująca się tożsamość w społeczeństwie wielokulturowym a edukacja międzykulturowa. In: Nikitorowicz, J., Sobecki, M. and Misiejuk, D. eds. Kultury tradycyjne a kultura globalna, konteksty edukacji międzykulturowej. Białystok: Wydawnictwo Uniwersyteckie „Trans Humana”, pp. 15-35.

Nikitorowicz, J. 2003. Typy tożsamości człowieka w społeczeństwie zróżnicowanym kulturowo. Chowanna. 1 (20), pp. 50-66.

Nikitorowicz, J. 2005. Kreowanie tożsamości dziecka. Wyzwania edukacji międzykulturowej. Gdańsk: GWP.

Nikitorowicz, J. 2009. Edukacja regionalna i międzykulturowa. Warszawa: WAiP.

Nowak, A. ed. 2013-15. Historia Polski w XIX wieku. Vol. 1. Kominy, ludzie, obłoki, modernizacja i kultura. Vol. 2 and 3. Historia polityczna. Vol. 4. Narody, wyznania, emigracje, porównania. Kraków: Wydawnictwo DIG. Nowicka, E. ed. 1991. Religia a obcość. Kraków: Zakład Wydawniczy „Nomos".

Ogrodzka-Mazur, E. 1998. Tolerancja jako wartość w procesie edukacji międzykulturowej. In: Lewowicki, T. and Grabowska, B. eds. Młodzież i tolerancja (studium z pogranicza polsko-czeskiego). Cieszyn: UŚ - Filia w Cieszynie, pp. 82-98.

Ogrodzka-Mazur, E. 2009. Nowy nieporządek świata a kształtowanie (się) tożsamości globalnej. Ku pedagogice odpowiedzialności w XXI wieku. In: Lewowicki, T., Ogrodzka-Mazur, E. and Urban, J. eds. Społeczne uwarunkowania edukacji międzykulturowej. Vol. 1. Konteksty teoretyczne. Cieszyn - Warszawa - Toruń: Wydział Etnologii i Nauk o Edukacji Uniwersytetu Śląskiego, WSP ZNP w Warszawie, Wydawnictwo Adam Marszałek, pp. 85-99.

Ogrodzka-Mazur, E., Klajmon-Lech, U. and Różańska, A. 2014. Tożsamość kulturowa, religijność i edukacja religijna postrzegana z perspektywy spoteczności szkót z polskim językiem nauczania w wybranych krajach europejskich. Cieszyn - Toruń: UŚ, Wydawnictwo Adam Marszałek.

Olszański, T.A. 2020. Wyprawa kijowska. Tygodnik Powszechny. 20 (3697).

Paczkowski, A. 2006. Pót wieku dziejów Polski. Warszawa: Wydawnictwo Naukowe PWN.

Papuga, S. and Gramsz, A. 2003. Zelów, wspólnota nacji, wyznań i kultur. Łódź: Wydawnictwo Grako. 
Posern-Zieliński, A. 1987. Etniczność. In: Staszczak, Z. ed. Stownik etnologiczny: terminy ogólne. Warszawa - Poznań: PWN, pp. 79-80.

Pospiszył, W. 2013. Szkolnictwo mniejszości czeskiej w Zelowie i okolicach. In: Lewowicki, T., Nikitorowicz, J. and Szczurek-Boruta, A. eds. Szkoty dla mniejszości narodowych i społeczności kaszubskiej w Polsce - stan, problemy, perspektywy. Warszawa - Cieszyn - Białystok: Wyższa Szkoła Pedagogiczna ZNP w Warszawie, Wydział Etnologii i Nauk o Edukacji Uniwersytetu Śląskiego w Katowicach, Uniwersytet Białostocki, Stowarzyszenie Wspierania Edukacji Międzykulturowej, pp. 143-150.

Powszechny Sumaryczny Spis Ludności z dn. 14.II.1946 r. 1947. Warszawa: Nakładem Głównego Urzędu Statystycznego, Uzupełnienie - Suplement, p. XVI.

Rocznik Statystyki Rzeczypospolitej Polskiej. 1925. Warszawa: Nakładem GUS.

Rocznik Statystyczny Rzeczypospolitej Polskiej. 2015. Warszawa: GUS.

Romanowska, E. 2010. Szkoła białoruska w Polsce - od czasów II po III Rzeczpospolitą. In: Zaniewska, T. ed. Białorusini. Warszawa: Wydawnictwo Sejmowe, pp. 77-105.

Serczyk, W.A. 2009. Historia Ukrainy. Wrocław: Zakład Narodowy im. Ossolińskich.

Siemakowicz, M. 1997. Polityka władz rosyjskich, niemieckich i polskich wobec szkolnictwa białoruskiego w latach 1903-1922. Białoruskie Zeszyty Historyczne. 7, pp. 33-48.

Siemakowicz, M. 1998. Założenia programowe głównych obozów politycznych wobec szkolnictwa dla ludności białoruskiej w II Rzeczypospolitej. Białoruskie Zeszyty Historyczne. 9, pp. 58-77.

Siemakowicz, M. 1999a. Organizacja białoruskich gimnazjów i seminariów nauczycielskich w II Rzeczypospolitej. Białoruskie Zeszyty Historyczne. 11, pp. 126-147.

Siemakowicz, M. 1999b. Organizacja szkolnictwa dla ludności białoruskiej w II Rzeczypospolitej. Białoruskie Zeszyty Historyczne. 12, pp. 80-132.

Syrnyk, M. 2006. Doswid orhanizaciji ukrajinskoho szkilnyctwa w Polszczi pislia 1947 r. Ukrajinśkyj almanach. Warszawa.

Szczur, S. 2002. Historia Polski. Średniowiecze. Kraków: Wydawnictwo Literackie.

Szymański, M.S. 1995. Od pedagogiki dla cudzoziemców do pedagogiki międzykulturowej w Republice Federalnej Niemiec. In: Nikitorowicz, J. ed. Edukacja międzykulturowa. W kręgu potrzeb, oczekiwań i stereotypów. Białystok: Wydawnictwo Uniwersyteckie „Trans Humana”, pp. 92-103. 
Tobiański, Z. 1994. Czesi w Polsce. Kraków: Towarzystwo Społeczno-Kulturalne Czechów i Słowaków w Polsce. Zarząd Główny.

Witkowski, L. 2000. Uniwersalizm pogranicza. O semiotyce kultury Michała Bachtina w kontekście edukacji. Toruń: Wydawnictwo Adam Marszałek. Wojciechowski, O. 2013. Oświata litewska w Polsce. In: Lewowicki, T., Nikitorowicz,, J. and Szczurek-Boruta, A. Szkoty dla mniejszości narodowych i społeczności kaszubskiej w Polsce - stan, problemy i perspektywy. Warszawa - Cieszyn - Białystok: Wyższa Szkoła Pedagogiczna ZNP w Warszawie, Wydział Etnologii i Nauk o Edukacji Uniwersytetu Śląskiego w Katowicach, Uniwersytet Białostocki, Stowarzyszenie Wspierania Edukacji Międzykulturowej, pp. 23-34.

Wyrozumski, J. 1979. Historia Polski do roku 1505. Warszawa: PWN.

Wyrozumski, J. 1999. Dzieje Polski piastowskiej (VIII w.-1370). Kraków: Fogra. 